\title{
Sex differences in atherosclerosis \\ and exercise effects
}

\section{Liam J. Ward}

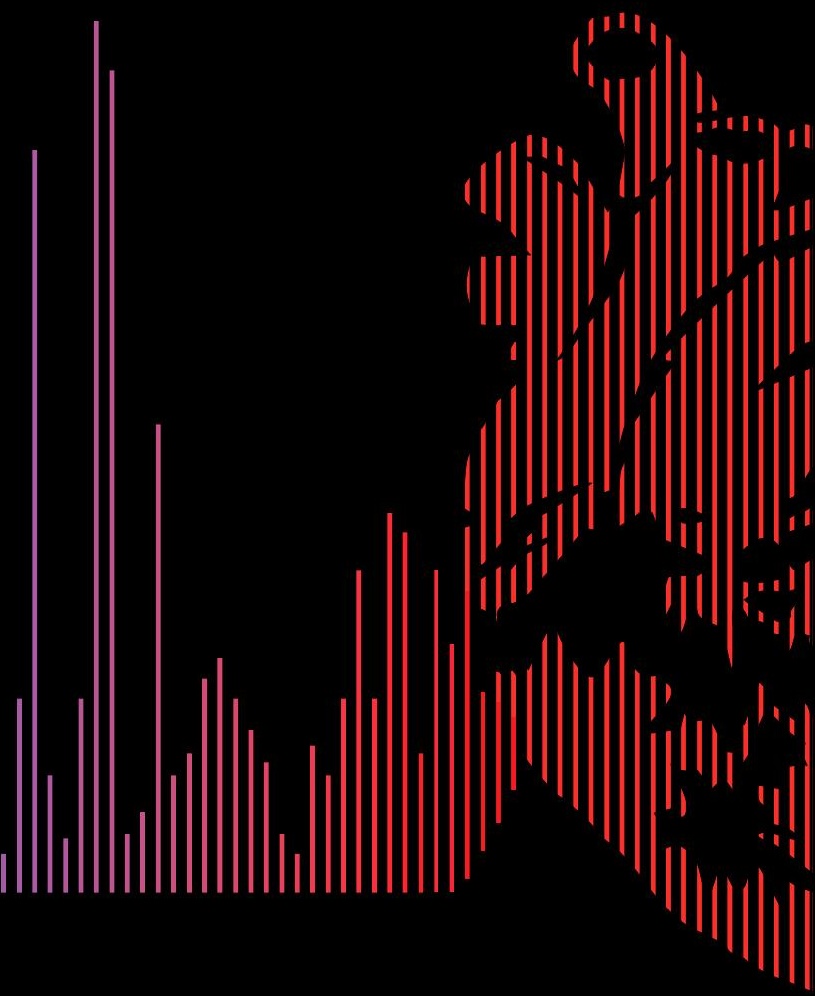


Linköping University Medical Dissertations No. 1676

\title{
Sex differences in atherosclerosis and exercise effects
}

\author{
Liam J. Ward
}

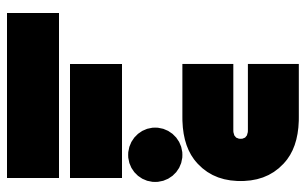

LINKÖPING UNIVERSITY

Division of Children's and Women's Health Department of Clinical and Experimental Medicine

Faculty of Medicine and Health Sciences

Linköping University, Sweden

Linköping 2019 
Copyright $@ 2019$ by Liam J. Ward

Cover design by Adam Kundurakis

ISBN: 978-91-7685-097-8

ISSN: 0345-0082

Published papers I and II are open access articles and published under the terms of the Creative Commons Attribution License (CC BY), meaning that authors retain ownership of the copyright for their article.

Published paper III has been reprinted with the permission of the copyright holders.

Printed in Linköping, Sweden by LiU-Tryck, April 2019 
"It would be so nice if something made sense for a change"

Alice's Adventures in Wonderland

by Lewis Carroll 


\section{SUPERVISOR}

Wei Li, MD, Associate Professor

Department of Clinical and Experimental Medicine, Linköping University, Sweden.

\section{CO-SUPERVISORS}

\section{Xi-Ming Yuan, MD, Associate Professor}

Department of Clinical and Experimental Medicine, Linköping University, Sweden.

\section{Helen Karlsson, Associate Professor}

Department of Clinical and Experimental Medicine, Linköping University, Sweden.

\section{Marie Rubér, PhD}

Department of Clinical and Experimental Medicine, Linköping University, Sweden.

\section{Anna-Clara Spetz Holm, MD, Associate Professor}

Department of Clinical and Experimental Medicine, Linköping University, Sweden.

\section{FACULTY OPPONENT}

\section{Magnus Grenegård, Professor}

Cardiovascular Research Center, School of Medical Sciences, Örebro University, Sweden.

\section{EXAMINATION BOARD}

\section{Karolina Kublickiene, Associate Professor}

Department of Clinical Science, Intervention and Technology, Karolinska Institute, Sweden.

\section{Karin Öllinger, Professor}

Department of Clinical and Experimental Medicine, Linköping University, Sweden.

\section{Gunilla Sydsjö, Adjunct Professor}

Department of Clinical and Experimental Medicine, Linköping University, Sweden. 


\section{ABSTRACT}

Cardiovascular disease (CVD) is the leading cause of death globally, with atherosclerosis being the main cause of cardiovascular diseases. Atherosclerosis is an inflammatory disease of the blood vessel wall, which over time will cause thickening and hardening of the vessel wall. Atherosclerosis can result in catastrophic vascular events, such as myocardial infarction and stroke. There are distinct sex differences in CVD mortality at different ages, before menopause women have a lower mortality of CVD in comparison to men, which equalises after menopause. In addition to sex differences in the incidence of CVD, there are also distinct sex differences in the phenotype of atherosclerotic plaques, with men generally developing more severe and vulnerable plaques that are at risk of rupture.

This thesis aimed to investigate the sex differences in atherosclerosis, in particular how the proteome and pathophysiology differs. In addition, we sought to investigate the potential benefit of an exercise programme, in reducing CVD risks, using a randomised controlled trial including postmenopausal women.

Sex differences in atherosclerosis were first investigated via proteomic analysis of human carotid endarterectomy samples. Initially, five intraplaque biopsies were taken from distinct atheroma regions, including; internal control, fatty streak, plaque shoulder, plaque centre, and fibrous cap. Protein extracts from these biopsies were subjected to analysis by mass spectrometry. The novel sampling method was successful in reducing the effect of plaque heterogeneity, a limitation in previous proteomic studies of atherosclerosis, and a number of previously unreported proteins were identified in human carotid atheroma. In addition to this, with the inclusion of multivariate statistical modelling, it was found that 43 proteins significantly discriminated the carotid atheroma between men and women. These proteins were grouped by function, and it was found that atheroma from men was associated with the increased abundance of inflammatory response proteins, including phospholipase-A2 membrane associated and lysozyme $\mathrm{C}$, and atheroma from women was associated with increased abundance of blood coagulation, complement activation, and transport proteins, notably including; antithrombin-III, coagulation factor XII, and afamin. In addition, differences were also 
observed in the abundance of iron metabolism related proteins. These sex differences were further expanded upon from a pathophysiological perspective. Immunohistochemistry stainings of ferritin and transferrin receptor 1 were found significantly increased in the atheroma from men. Moreover, the levels of plasma haemoglobin were also significantly increased in men and were associated with the development of more vulnerable and severe plaque types. The more vulnerable and severe plaque types were also associated with significantly greater macrophage infiltration. In summary, these results are indicative of men developing atheroma with greater inflammation that are more vulnerable, due to increased iron and inflammatory proteins and macrophage infiltration, whereas atheroma from women develop with less inflammation and a more stable phenotype.

The randomised controlled clinical trial aimed at investigating the effects of resistance training (RT), over a 15-week period, in postmenopausal women. Plasma samples were obtained at week- 0 and week-15 of the study period, and analyses were performed primarily using a series of immunoassays. Results showed that women participating in RT, with good compliance, were associated with significant decreases in plasma levels of ferritin, lipids, and inflammatory adipokines. These results suggest that the use of regular RT may be a beneficial intervention in reducing the levels of body iron, lipids, and inflammation, all of which are risk factors for the development of CVD. However, validation studies are required in a larger cohort of postmenopausal women, in addition to the inclusion or complementary studies in middle-aged men.

In summary, the works included in this thesis further expand on the current knowledge of sex differences in atherosclerosis, and also provides information on the potential of an exercise intervention to beneficially reduces the effects of known risk factors of CVD. 


\section{POPULAR SCIENTIFIC SUMMARY}

Cardiovascular diseases (CVD), such as heart attacks and strokes, are the biggest causes of death globally. The main cause of CVD is called atherosclerosis, which is a process where the blood vessels become narrower and stiffer due to stored fats and dying cells, and inflammation in the blood vessel wall. Atherosclerosis can affect major arteries including the coronary and carotid arteries, which provide oxygenated blood to the heart and brain, respectively. The amount of CVD-related deaths is disproportional between the sexes at different ages; before menopause, fewer women die of CVD than men, which then equalises after menopause. In addition, atherosclerosis in men seems to develop with a greater risk profile, being more vulnerable to rupture and blocking the artery, than atherosclerosis in women. The reasoning behind these differences are largely unclear and more research is needed to understand why such differences occur.

This thesis aimed to investigate the sex differences in atherosclerosis further from two main perspectives, including; proteomics and pathophysiology. Proteomics is the study of all proteins within a specified cell, tissue, or organism, and pathophysiology is the study of physiological processes associated with a specified disease or injury. In addition, works in this thesis also evaluated the potential of an exercise programme aimed to reduce the CVD risk profile in postmenopausal women, a population group that is at risk of developing CVD.

Proteomic analyses were performed on atherosclerotic carotid arteries obtained from both men and women, from these, five biopsies were taken from distinct regions of each artery. Proteins were extracted from these biopsies and broken down into smaller components called peptides. These are analysed using mass spectrometry, a method that measures the peptide masses, creating a mass pattern. Since every protein has a specific mass pattern, a database search is made to match the mass patterns to find out which proteins are in the sample. Taking samples from multiple regions in the atherosclerotic artery allowed for more proteins to be identified in the samples, in comparison to previous studies using similar methods. When analysing the data from proteomic analyses to identify sex differences, it was found that proteins within 16 
groups discriminated the protein profile between men and women. Atherosclerotic arteries from men had a higher abundance of proteins involved in inflammation, which is a key promoter of atherosclerosis development. Atherosclerotic arteries from women had a higher abundance of proteins involved in blood coagulation and complement activation, both systems play roles in blot clot formation, and transport proteins. In addition, differences in proteins related to iron metabolism in the body were found, and expanded experiments were performed to study these further. Immunohistochemistry, a method which stains sections of tissues for specific proteins that can then be viewed under the microscope, was used to stain for the expression of iron-related proteins, ferritin and transferrin receptor-1, and macrophages, a cell type associated with inflammation and vulnerability in atherosclerosis. The results of these experiments found that levels of iron-related proteins were higher in atherosclerotic arteries from men, compared to women, and that these high levels were associated with higher levels of macrophages and greater severity of atherosclerotic artery. In summary, a number of proteins were identified that discriminate the atherosclerosis protein profile between men and women, which in addition to immunohistochemistry differences can contribute to the understanding of atherosclerosis development and vulnerability.

An exercise programme was used to evaluate its effect on reducing potential CVD risks in a group of postmenopausal women. The exercise programme was based on 15 weeks of resistance training and women included were randomised into two groups to either receive the exercise training or be a control group and not alter their physical activity levels. Blood samples were taken at two time points in the trial, weeks 0 and 15 , and analysed for a wide variety of markers, including fats, iron-metabolism markers, and inflammation markers. To summarise, the trial found that women who participated in the exercise, with good compliance, were associated with significant reductions in the blood levels of fats, ferritin (an iron transport protein), and inflammatory markers derived from body fat - termed adipokines.

In summary, the works included in this thesis further expand on the current knowledge of sex differences in atherosclerosis, and also provides information on the potential of an exercise programme that could beneficially reduce risk of CVD. 


\section{POPULÄRVETENSKAPLIG SAMMANFATTNING}

Hjärt- och kärlsjukdomar (CVD), såsom hjärtinfarkt och stroke, är den ledande dödsorsaken över hela världen. Huvudorsaken till CVD är ateroskleros (även kallat åderförfettning/åderförkalkning), vilken är en process där blodkärlen blir trängre och stelare på grund av inlagrat fett, döende celler och inflammation i blodkärlsväggarna. Ateroskleros kan påverka stora artärer, inklusive krans- och karotidartärer, vilka förser syrerikt blod till hjärtat respektive hjärnan. Antalet dödsfall till följd av CVD är oproportionellt mellan män och kvinnor i olika åldersgrupper. Före klimakteriet dör färre kvinnor än män av CVD, vilket jämnas ut efter klimakteriet. Hos män utvecklas dessutom ateroskleros med större riskprofil, som är känsligare för bristningar och blockerande av blodflöde än ateroskleros hos kvinnor. Orsakerna till skillnaderna är oklara och mer forskning behövs inom området.

Denna avhandling avser att undersöka könsskillnader i ateroskleros utifrån två perspektiv, proteomik och patofysiologi. Proteomik är läran om alla proteiner inom en specificerad cell, vävnad, eller organism, och patofysiologi är läran om fysiologiska processer associerade med specificerad sjukdom eller skada. Avhandlingen utvärderar dessutom potentialen av ett träningsprogram ämnat att reducera CVD-riskprofilen hos kvinnor efter klimakteriet, vilka är inom riskgruppen att utveckla CVD.

Proteomikanalyser utfördes på aterosklerotiska karotidartärer från män och kvinnor, där fem biopsier togs från distinkta regioner i varje karotidartärsprov. Proteiner extraherades från biopsierna och klyvdes ner till mindre beståndsdelar som kallas peptider. Dessa analyserades seden med masspektrometri vilket är en metod som initialt bryter ner proteinerna i mindre fragment och mäter dess massa som summeras i ett massmönster. Då varje protein ger ett specifikt massmönster, görs en efterföljande databassökning som matchar mätresultatets massmönster för att få fram vilka proteiner som finns i provet. Prover från flera regioner i den aterosklerotiska artären tillät identifikation av fler proteiner än vad som gjorts i tidigare studier med liknande metoder. Proteomikanalyserna visade på 16 proteingrupper som urskilde proteinprofilen mellan män och kvinnor. Aterosklerotiska artärer från män hade en större majoritet av proteiner involverade i inflammation, vilka har en nyckelroll i 
utvecklingen av ateroskleros. Aterosklerotiska artärer från kvinnor hade en större andel proteiner involverade i blodkoagulering och komplementaktivering, två mekanismer delaktiga i bildning av blodproppar, men även proteiner involverade i transport av olika ämnen $\mathrm{i}$ kroppen. Vidare upptäcktes skillnader i proteiner kopplade till ämnesomsättning av järn i kroppen, där utökade experiment genomfördes för att vidare studera skillnaderna. Immunohistokemi är en metod som färgar delar av vävnader för specifika proteiner och som sedan kan studeras i mikroskop. Denna metod användes för att färga in de järnrelaterade proteinerna, ferritin och transferrinreceptor-1, samt makrofager som är en celltyp kopplad till inflammation och sårbarhet i aterosklerotiska artärer. Resultaten av dessa experiment visade att nivåer av järn-relaterade proteiner var högre i aterosklerotiska artärer hos män, jämfört med kvinnor, och att dessa höga nivåer kunde relateras till fler makrofager och stelare aterosklerotiska artärer. Sammanfattningsvis identifierades proteinprofiler där ett flertal proteiner skilde mellan män och kvinnor, vilket tillsammans med patofysiologiska skillnader skulle kunna bidra till vidare förståelse för bildandet av ateroskleros och dess sårbarhet.

Ett träningsprogram tillämpades för att utvärdera dess effekt på att minska risken för CVD i en grupp kvinnor efter klimakteriet. Träningsprogrammet innefattade 15 veckors resistensträning där de inkluderade kvinnorna slumpades in i två grupper. Ena gruppen tilldelades träningsprogrammet $\mathrm{i}$ fråga medan den andra blev kontrollgrupp och därmed inte skulle förändra sin fysiska aktivitetsnivå. Blodprover togs vid två tillfällen under försöket, vecka 0 och vecka 15 , och analyserades för ett brett urval av markörer, inklusive fetter, järnomsättnings- samt inflammationsmarkörer. Försöket visade att kvinnor som deltog i träningen med god följsamhet, hade kopplade minskade nivåer av fetter, ferritin (ett järntransportprotein) och adipokiner (inflammationsmarkörer från kroppsfett) i blodet

Sammanfattningsvis så bidrar arbetet $\mathrm{i}$ denna avhandling till kunskaperna om könsskillnader $\mathrm{i}$ ateroskleros och ger även information om potentialen för ett träningsprogram som skulle kunna reducera riskerna för CVD. 


\section{LIST OF PAPERS INCLUDED IN THIS THESIS}

This thesis is based on the following papers, referred to in the text by their Roman numerals:

\section{Paper I}

Wenzhao Liang*, Liam J. Ward*, Helen Karlsson, Stefan A. Ljunggren, Wei Li, Mats Lindahl, \& Xi-Ming Yuan.

Distinctive proteomic profiles among different regions of human carotid plaques in men and women. Scientific Reports. 2016; 6:26231.

\section{*Authors contributed equally}

\section{Paper II}

Liam J. Ward, Patrik Olausson, Wei Li, \& Xi-Ming Yuan.

Proteomics and multivariate modelling reveal sex-specific alterations in distinct regions of human carotid atheroma. Biology of Sex Differences. 2018; 9:54.

\section{Paper III}

Xi-Ming Yuan*, Liam J. Ward*, Claes Forssell, Nabeel Siraj, \& Wei Li.

Carotid atheroma from men has significantly higher levels of inflammation and iron metabolism enabled by macrophages. Stroke. 2018; 49:419-425.

*Authors contributed equally

\section{Paper IV}

Liam J. Ward, Mats Hammar, Lotta Lindh-Åstrand, Emilia Berin, Hanna Lindblom, Marie Rubér, Anna-Clara Spetz Holm, \& Wei Li.

Resistance training is associated with significantly reduced plasma levels of ferritin and atherogenic lipids, but not oxidative stress markers, in postmenopausal women: a randomised controlled trial. Manuscript.

\section{Paper V}

Liam J. Ward, Sigrid Nilsson, Mats Hammar, Lotta Lindh-Åstrand, Emilia Berin, Hanna Lindblom, Anna-Clara Spetz Holm, Wei Li, \& Marie Rubér

Resistance training is associated with significantly reduced plasma adipokine levels in postmenopausal women: a randomised controlled trial. Manuscript. 


\section{PAPERS OUTSIDE OF THIS THESIS}

Fredrik Iredahl, Veeranjaneyulu Sadda, Liam J. Ward, Johannes Hackethal, Simon Farnebo, Erik Tesselaar, \& Folke Sjöberg.

Modeling perfusion dynamics in the skin during iontophoresis of vasoactive drugs using singlepulse and multiple-pulse protocols. Microcirculation. 2015; 22:446-453.

Xi-Ming Yuan, Nargis Sultana, Liam J. Ward, Bijar Ghafouri, \& Wei Li.

Autophagy induction protects against 7-oxysterol induced cell death via lysosomal pathway and oxidative stress. Journal of Cell Death. 2016; 9:1-7.

Wei Li, Nargis Sultana, Liam J. Ward, Monika Pawlik, Efrat Levy, Stefan Jovinge, Eva Bengtsson, \& Xi-Ming Yuan.

Autophagy dysfunction and regulatory cystatin $\mathrm{C}$ in macrophage death of atherosclerosis. Journal of Cellular and Molecular Medicine. 2016; 20(9):1664-1672.

Liam J. Ward, Stefan A. Ljunggren, Helen Karlsson, Wei Li, \& Xi-Ming Yuan.

Exposure to atheroma-relevant 7-oxysterols causes proteomic alterations in cell death, cellular longevity, and lipid metabolism in THP-1 macrophage. PLoS One. 2017; 12(3): e0174475.

Sara Oppi, Stefanie Nusser-Stein, Przemyslaw Blyszcuk, Xu Wang, Simone Marzolla, Elena Osto, Liam J. Ward, Xi-Ming Yuan, Alaa Othman, Thorsten Hornemann, Zoran Rancic, Stefanie D. Krämer, Dongryeol Ryu, Maaike H. Oosterveer, Thomas F. Lüscher, \& Sokrates Stein.

Macrophage NCOR1 protects from atherosclerosis by blocking the proatherogenic oxLDLPPAR $\gamma$-CD36 pathway. Manuscript in submission. 


\section{TABLE OF CONTENTS}

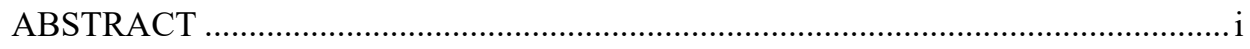

POPULAR SCIENTIFIC SUMMARY .................................................................ii

POPULÄRVETENSKAPLIG SAMMANFATTNING .............................................

LIST OF PAPERS INCLUDED IN THIS THESIS ............................................... vii

PAPERS OUTSIDE OF THIS THESIS ................................................................. viii

TABLE OF CONTENTS ......................................................................................... ix

ABBREVIATIONS .........................................................................................

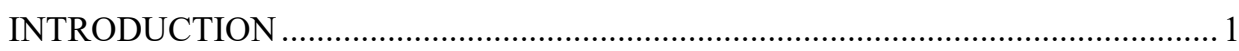

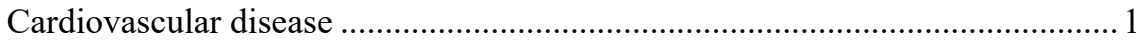

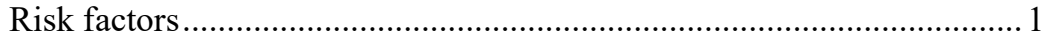

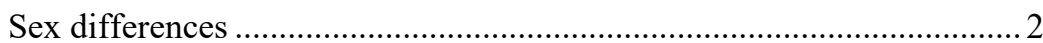

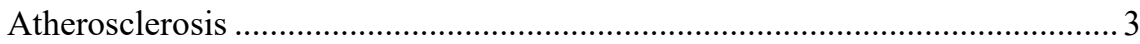

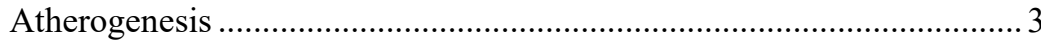

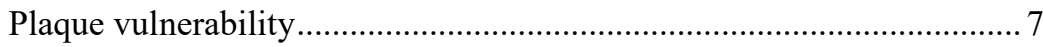

Plaque rupture and thrombus formation ............................................ 8

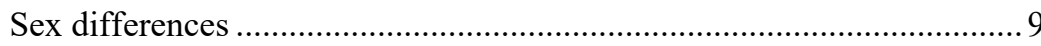

Proteomics in atherosclerosis research ........................................................... 10

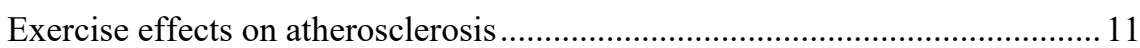

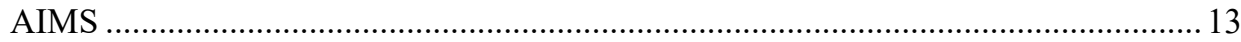

COMMENTS ON MATERIALS AND METHODS .............................................. 15

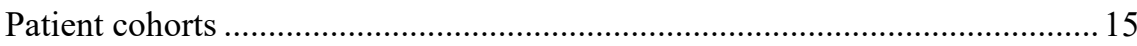

Linköping Carotid Study (Papers I-III) ............................................ 15

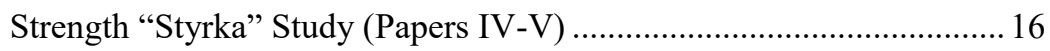

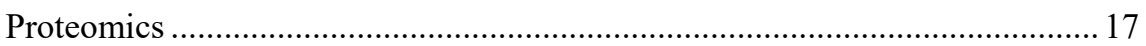

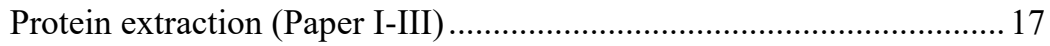

Two-dimensional gel electrophoresis (Paper I) ................................. 17

MALDI-TOF mass spectrometry (Paper I) ........................................ 18

Tandem-mass spectrometry (Papers I-III)........................................ 20

Multivariate statistical modelling (Paper II) ....................................... 20

Immunohistochemistry (Papers I \& III) ....................................................... 21 


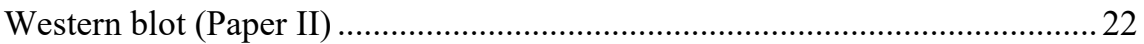

Enzyme-linked immunosorbent assay (Papers IV-V) ......................................... 23

Multiplex bead array (Paper V) ...................................................................... 24

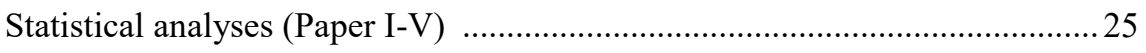

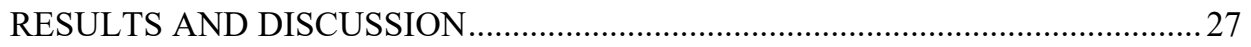

"Deconstructing" the atheroma proteome (Paper I) ..........................................2 27

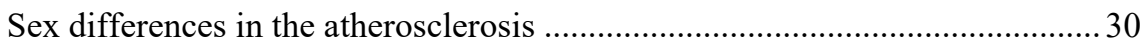

Proteomic perspective (Paper II) ......................................................... 31

Pathophysiology perspective (Paper III) …………………………….... 35

Resistance training effects in postmenopausal women ......................................39

RT associated effects on iron status and lipids (Paper IV) ..................... 41

RT associated effects on adipokines and hormones (Paper V) ................ 44

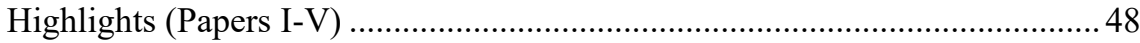

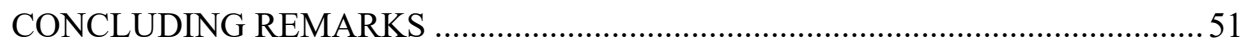

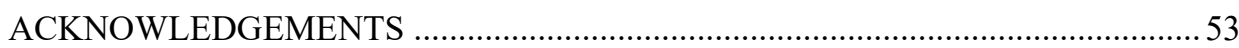

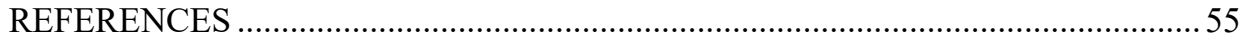




\section{ABBREVIATIONS}

2-DE

AT-III

BMI

CCD

CRP

CVD

ECM

ELISA

FXII

$\mathrm{Hb}$

HDL

HRP

IFN- $\gamma$

IHC

IL

IPH

LC

LDL

$\mathrm{m} / \mathrm{z}$

MALDI-TOF

MCP-1

MMP

MS

nLC-MS/MS

NO

oxLDL

ROS

RT

SDS-PAGE

Serpin

SHBG

SMC

${ }_{3} \mathrm{PLA}_{2}$-IIA

TfR1

TNF- $\alpha$
Two-dimensional gel electrophoresis

Antithrombin-III

Body mass index

Charge-coupled device

C-reactive protein

Cardiovascular disease

Extracellular matrix

Enzyme-linked immunosorbent assay

Coagulation factor XII

Haemoglobin

High-density lipoprotein

Horseradish peroxidase

Interferon- $\gamma$

Immunohistochemistry

Interleukin

Intraplaque haemorrhage

Liquid chromatography

Low-density lipoprotein

Mass-to-charge ratio

Matrix-assisted laser desorption/ionisation time-of-flight

Monocyte chemoattractant protein-1

Matrix metalloproteinase

Mass spectrometry

Nano-liquid chromatography tandem-mass spectrometry

Nitric oxide

Oxidised low-density lipoprotein

Reactive oxygen species

Resistance training

Sodium dodecyl sulphate-polyacrylamide gel electrophoresis

Serine protease inhibitor

Sex hormone binding globulin

Smooth muscle cell

Phospholipase A2, membrane associated

Transferrin receptor 1

Tumour necrosis factor- $\alpha$ 


\section{INTRODUCTION}

\section{Cardiovascular disease}

Cardiovascular disease (CVD) relates to all diseases of the heart and blood vessels, with the etymology deriving from the Greek word "kardia" and Latin word "vascularis". CVD encompasses a variety of diseases originating from the heart, including; heart failure, valvular heart disease, cardiac dysrhythmias, etc., and the blood vessels, including; coronary/peripheral artery disease, cerebrovascular disease, aortic aneurysm, etc.

In 2016, it was estimated that 17.8 million people died from CVD, $31 \%$ of all deaths, making it the greatest cause of death globally. ${ }^{1}$ The two most common causes of death, and in turn common CVDs, are ischaemic heart disease (colloquially: "heart attack") and stroke accounting for 16\% and $10 \%$ of deaths, respectively. ${ }^{1}$ CVD disproportionally affects low- and middle-income countries, accounting for more than $75 \%$ of CVD deaths. In highincome countries, such as those in Western Europe and North America, CVD mortality has declined, however, it still remains the most common cause of This thesis, and the accompanying works, were produced in Sweden. Thus, specific figures relating to CVD mortality in Sweden are as follows: In 2016, it was estimated that 31.6 thousand people died from CVD, 34\% of all deaths. As with the global trend, CVD is the greatest cause of death in Sweden. ${ }^{1}$ death. ${ }^{1,2}$

\section{Risk factors}

There are several risk factors associated with the development of CVD that have been studied extensively in epidemiology. The Framingham Heart Study, commissioned in 1948, was one of the largest cardiovascular epidemiology studies and has contributed to some of the most significant insights to CVD risk factors. This study first identified major CVD risk factors such as high blood cholesterol, high blood pressure, smoking, obesity, physical inactivity, and diabetes. ${ }^{3}$ Recently, the 
INTERHEART case-control study, which included over 29,000 participants from 52 countries across all inhabited continents, investigated the relationship between myocardial infarction and several risk factors. ${ }^{4}$ The INTERHEART results provided evidence that smoking, abnormal lipids, hypertension, diabetes, abdominal obesity and psychosocial factors were positively associated with the risk of myocardial infarction, where fruit/vegetable consumption and physical activity were negatively associated with risk of myocardial infarction. These associations were found in both men and women, irrespective of age, across all regions of the world. ${ }^{4}$

\section{Sex differences}

In social terms, CVD has always been thought to be the disease of men. Though factually incorrect, this misconception is rooted in the incidence of CVD across the population at different ages. In general, CVD presents itself in men at a younger age than women. The global CVD mortality for persons aged 30-59 years shows a distinct bias with an approximate 65:35 ratio between men and women. ${ }^{1}$ However, when reassessing the CVD mortality in the older population, $60+$ years, this bias somewhat balances out at an approximate 50:50 ratio between men and women (Figure 1). ${ }^{1}$

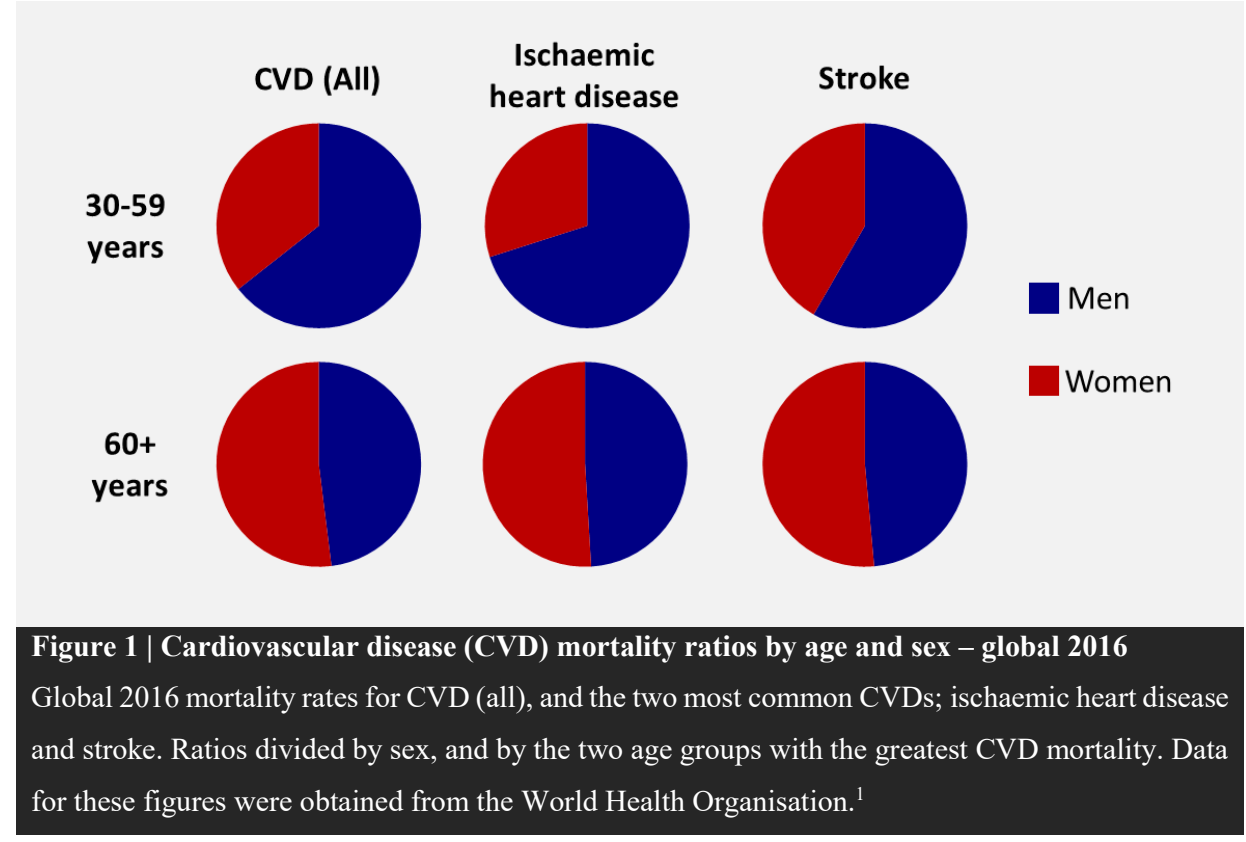




\section{Atherosclerosis}

Atherosclerosis is the leading cause of CVD, including coronary artery disease, cerebrovascular disease, and peripheral vascular disease. The term atherosclerosis comes from the Greek words "athere" and "sclerosis" meaning gruel and hard, respectively, and was originally coined by German pathologist Félix Marchand in $1904 .^{5}$ Atherosclerosis describes the thickening and hardening of arteries, which over time can lead to reduced and/or restricted blood flow. In simple terms: arterial thickening occurs from the buildup of a plaque in the intima of the arterial wall, which then gradually expands narrowing the arterial lumen. In advanced cases, plaques can rupture into the lumen causing thrombosis, blood clot formation, occluded the artery and restricting blood flow (Figure 2).

\section{Atherogenesis}

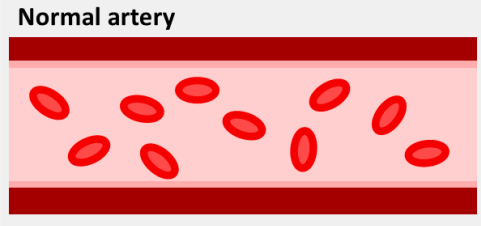

Plaque build-up

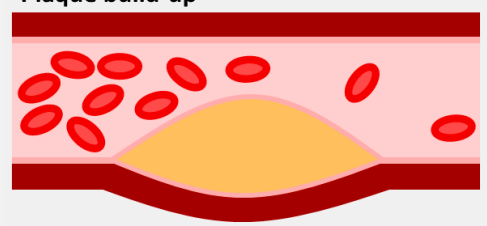

\section{Plaque rupture}
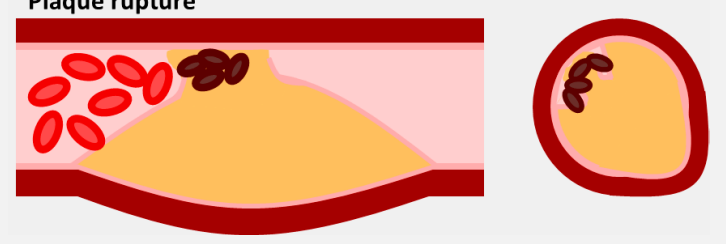

\section{Figure 2 | The atherosclerotic plaque.}

Illustration depicting the progression of plaque formation in the artery. (Top) Normal artery, with normal blood flow; (Middle) Atherosclerotic artery with plaque build-up, causing a reduced blood flow; (Bottom) Atherosclerotic artery with a ruptured plaque, causing thrombosis and blocking blood flow.

The process in which an atherosclerotic plaque forms within a blood vessel is called atherogenesis. Atherosclerosis is multifaceted, with many factors contributing to the initiation and progression of atherogenesis; however, one key component is common throughout the process: inflammation. Atherosclerosis is a progressive inflammatory disease of the vessel wall. ${ }^{6}$ Inherently, inflammation involves both branches of the immune system, innate and adaptive immunity, and both are involved, in some capacity, in atherogenesis. ${ }^{7}$ 
One of the most well-studied theories in atherogenesis is the 'response-to-injury' hypothesis, initially developed by Russell Ross, proposing that atherogenesis starts from a point of activation and injury/dysfunction of the endothelial cell layer on the inner side on the blood vessel. ${ }^{6,8}$ The injury to endothelial cells can derive from either mechanical, physiological, or immunological causes, such as laminal sheer stress, exposure to CVD risk factors (e.g. free radicals), or infection, respectively. These disturbances can activate the endothelial cells inducing a phenotype promoting the expression of proinflammatory cytokines, adhesion molecules, and chemoattractants. ${ }^{9}$ Activation implies resolution, which is possible, however, in the event of uncontrolled or prolonged endothelial cell activation this can lead to cell apoptosis (irreversible damage) or dysfunction (increased permeability)..$^{10}$ In both instances, increases in vascular cell adhesion molecule-1 (VCAM-1) promotes the recruitment of circulating immune cells to the endothelium. ${ }^{10}$ Recruited immune cells, monocytes and T-cells, migrate from the endothelium to the intima under the stimulation of chemoattractants, such as monocyte chemoattractant protein-1 (MCP-1) and interferon-inducible T-cell chemoattractant (ITAC). ${ }^{11,12}$

Monocytes and differentiated macrophages, are innate immune cells that play pivotal roles in atherogenesis (Figure 3). Monocytes that migrate into the intima of the vessel wall differentiate into macrophages, which have been seen to accumulate in human atherosclerotic lesions. ${ }^{13-15}$ Herein, macrophages express scavenger receptors, such as macrophage scavenger receptor types I and II (MSR1), scavenger receptor class B member 1 (SRB1), and cluster of differentiation 36 (CD36), amongst others. ${ }^{16}$ Scavenger receptors recognise various forms of lipoproteins that are subsequently engulfed by macrophages. MSR1 is highly expressed in tissue macrophages and has a high affinity for modified forms of low-density lipoprotein (LDL), such as oxidisedLDL (oxLDL) or acetylated-LDL. ${ }^{17}$ SRB1 and CD36 also have the capacity to bind oxLDL, as well as other lipoprotein fractions such as high-density lipoprotein (HDL) and very-low-density lipoprotein (VLDL). ${ }^{16}$ Accumulation of oxLDL then occurs inside the macrophages as the proinflammatory microenvironment of the atherosclerotic lesion inhibits lipid efflux. ${ }^{18}$ This accumulation results in a 

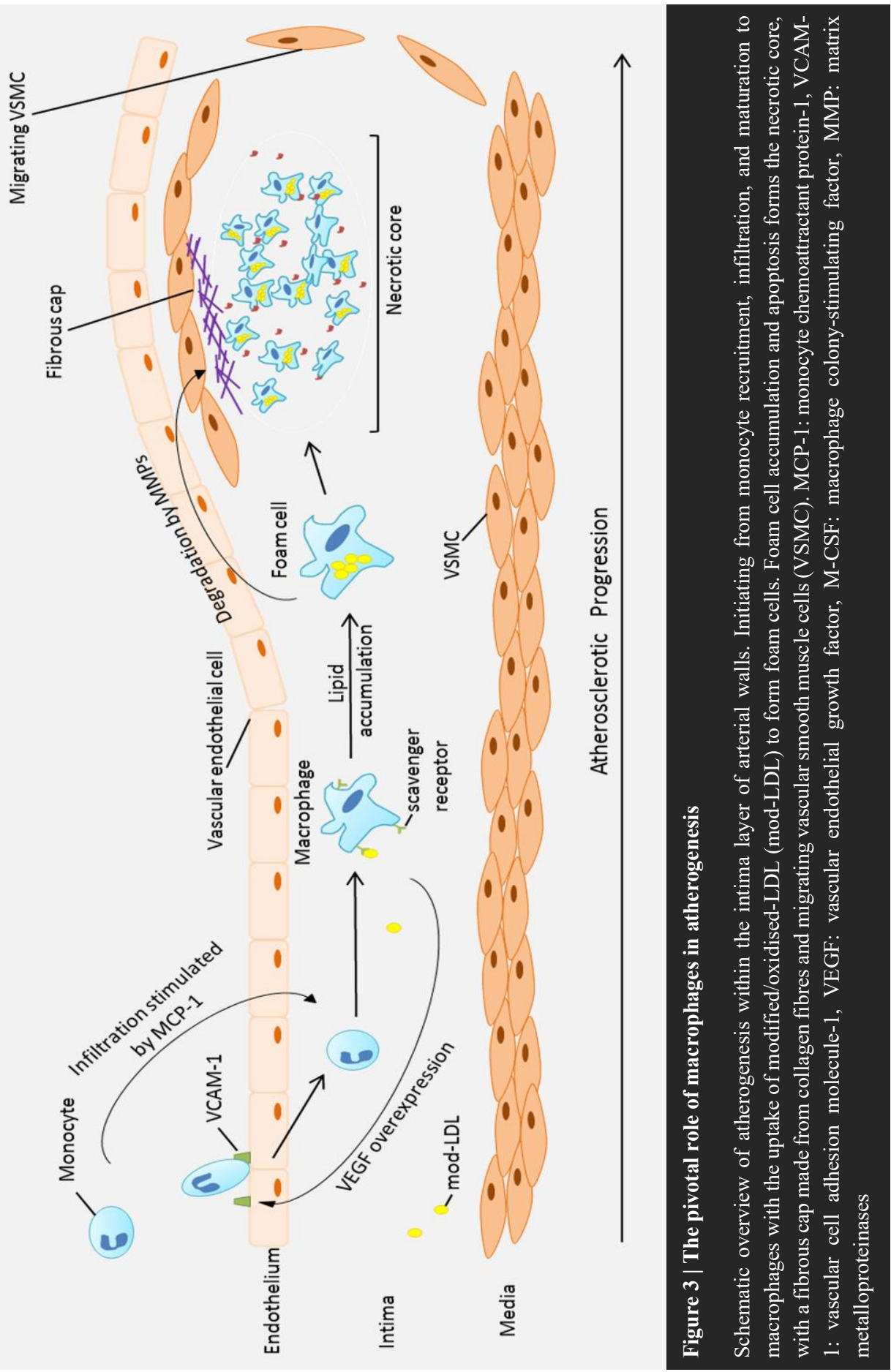
morphological change of macrophages to foam cells, which are unable to leave the intima and further contribute to inflammation in the atherosclerotic plaque. The buildup of these lipid-laden foam cells in the intima produces the first visible sign of atherosclerosis - a fatty streak, a white/yellow discolouration of the vessel wall. Though macrophages are the most studied population of cells known to develop into foam cells, it must also be noted that foam cells from non-myeloid origins, such as endothelial and smooth muscle cells (SMC), have also been found in atherosclerotic lesions. ${ }^{19}$ In normal conditions, foam cells would undergo cell death, and resulting debris would be cleared from the environment via efferocytosis. In advanced atherosclerotic lesions, this efferocytosis is impaired, due to the increasingly inflammatory microenvironment, resulting in apoptotic foam cells undergoing secondary necrosis. ${ }^{20}$ Macrophages, SMC, and other cells types have been demonstrated to undergo apoptosis in atherosclerotic lesions. ${ }^{14,15,21,22}$ Apoptotic or post-apoptotic necrotic foam cells release a number of inflammatory cytokines and growth factors, creating a feedback loop perpetuating inflammation and foam cell formation, in addition to the release of matrix metalloproteinases (MMP) and lysosomal cathepsins that degrade the extracellular matrix. ${ }^{15,22-25}$ These processes ultimately lead to the formation of a necrotic core in an atherosclerotic lesion.

The necrotic core constitutes the major component of advanced atherosclerotic plaques, which grows over time, thickening the vessel wall and restricting the blood flow. Necrotic core formation represents irreversible changes to the normal structure of the intima with the degradation of extracellular matrix (ECM) and deposition of lipids and cell debris, termed "gruel". ${ }^{26}$ As the necrotic core expands and the intima thickens, SMC migrate from the media layer of the vessel to the top of the necrotic core and, in combination with a collagenous matrix, forms a fibrous cap over the necrotic core. This fibrous cap hardens and helps to stabilise the atherosclerotic plaque from rupture into the lumen of the vessel.

In vulnerable atherosclerotic plaques, this fibrous cap is thinned by proteolytic enzymes released by foam cells, such as cathepsins and MMPs. Additionally, in atherosclerotic lesions, there are pronounced areas of hypoxia, specifically around the 
necrotic core. These areas of hypoxia can stimulate the release of hypoxia-induced factor $1 \alpha(\mathrm{HIF} 1 \alpha) .{ }^{27} \mathrm{HIF} 1 \alpha$ can stimulate angiogenesis of the vaso vasorum, small vessels that supply blood to the artery wall towards the hypoxic areas of the atherosclerotic plaque. ${ }^{28}$ As described, the atherosclerotic microenvironment is highly inflammatory and has a high level of proteolytic activity; such new vascularisation is prone to rupture causing intraplaque haemorrhage (IPH) - a risk factor for plaque destabilisation and rupture. ${ }^{27,28}$

\section{Plaque vulnerability}

Atherosclerosis is a chronic progressive disease that can originate from adolescence at a subclinical level through to mid-life and beyond where it may present clinically via CVD. Lesions are nominally classified in terms of lipid accumulation in the early stages (types I-III) and then by plaque vulnerability in the latter stages (types IV-VI). Type I lesions, which can occur from adolescence, comprise of isolated macrophage foam cells within the vessel wall. Type II lesions are characterised by the formation of fatty streaks. Type III lesions are characterised by the presence of fatty streaks with small extracellular lipid pools. Type IV lesions are the first type with a pronounced extracellular lipid/necrotic core. Type V lesions develop a fibrous cap above the lipid/necrotic core. Type VI lesions are complicated lesions that may contain IPH and/or have ruptured. ${ }^{29}$

As implied with the classification, the higher the classification the greater vulnerability the atherosclerotic plaque has to rupturing, potentially causing a catastrophic event such as myocardial infarction or stroke. There are a number of determinants that affect the vulnerability of the atherosclerotic plaque, with major ones including: the level of inflammation, the thickness of the fibrous cap, and the level of proteolytic enzymes. ${ }^{30}$ These determinants are very much intertwined when describing plaque vulnerability. Inflammation is the driving force of atherogenesis, aptly described above, and as such, a greater inflammatory profile propagates the recruitment of immune cells to the atherosclerotic microenvironment. Activated immune cells, such as neutrophils and macrophage foam cells, as well as SMC release proteolytic enzymes into the microenvironment. The increasing proteolytic activity in the plaque serves to 
degrade the ECM and thin the fibrous cap, leading to plaque vulnerability. Several proteolytic enzymes are found present at increased levels in atherosclerotic plaques, of which MMPs are some of the most studied. In healthy arteries, there is little or no MMP activity, whereas in arteries with atherosclerosis MMP activity is present. In vulnerable plaques, the activity of MMP-8 and MMP-9 are significantly greater than in stable plaques. ${ }^{31,32}$ MMP-8 and -9 , which degrade gelatin and collagen fibres, have been shown to have predictive power for cardiovascular events in population-based studies. $^{33-36}$

In addition, the role of iron and associated oxidative stress has been implicated in atherosclerotic plaques. ${ }^{37-41}$ Free iron, and other transition metals, can catalyse the formation free radicals, including reactive oxygen species (ROS) production. ${ }^{42}$ Free radicals have one or more unpaired electrons and have an increased reactivity, which is a risk factor for atherosclerosis. ${ }^{43}$ Iron is found in numerous molecules biologically, notably the haem-proteins - haemoglobin, hemopexin, haptoglobin - and iron transport proteins - ferritin and transferrin. ${ }^{44}$ Within the proteolytic environment of the atherosclerotic plaque these proteins can be broken down, releasing free iron with the potential to increase oxidative stress. Increased ROS levels stimulate a number of mechanisms in atherogenesis, including; endothelial dysfunction, oxidation of LDL, immune cell migration and differentiation, and cathepsins and MMP release..$^{15,22,24,45}$

\section{Plaque rupture and thrombus formation}

Key determinants of plaque rupture include a thin-fibrous cap, a large necrotic core, IPH, inflammatory cell infiltration, and low SMC density in the fibrous cap. ${ }^{46,47}$ Plaque rupture exposes the underlying vascular and necrotic core elements to the blood stream, which stimulate the recruitment of platelets and also activates a protein called tissue factor. ${ }^{48,49}$ Platelets adhere to molecules exposed by rupture, such as collagen, and become activated. Activated platelets in turn release molecules to facilitate platelet aggregation and activation of circulating coagulation factors. Activated coagulation factors perpetuate the coagulation cascade, of which tissue factor is the first step of the extrinsic pathway (Figure 4). ${ }^{49}$ The coagulation cascade ends with thrombin catalysing the conversion of fibrinogen to fibrin, which constitutes the matrix for the formation of 
a thrombus. ${ }^{49}$ Moreover, thrombin creates a feedback loop with a number of coagulation factors in the intrinsic pathway (Figure 4). The formation of a thrombus at the site of plaque rupture poses a severe risk for blocking blood flow or breaking away and blocking blood flow downstream in a smaller vessel, potentially causing an ischaemic event like myocardial infarction or stroke.

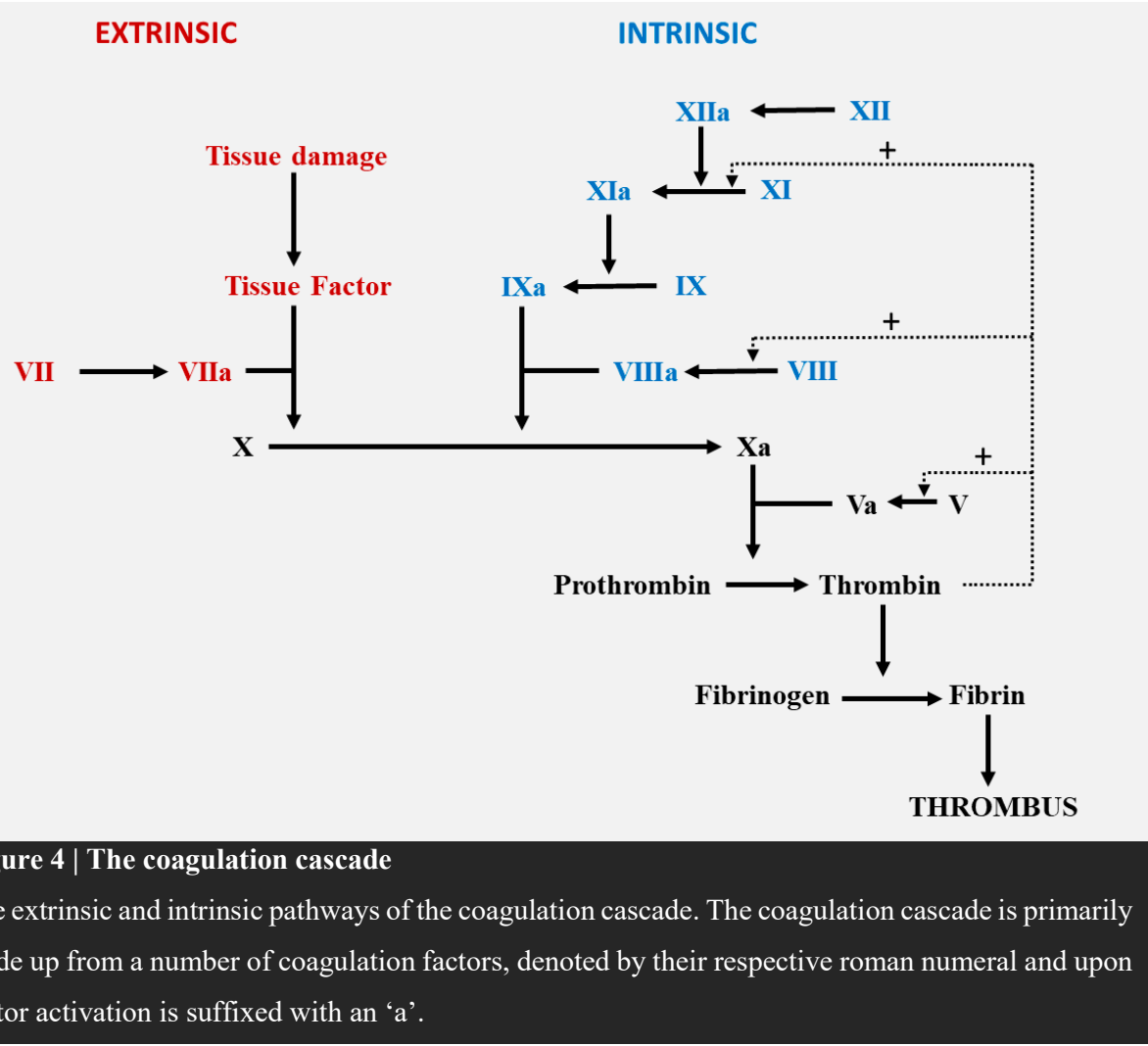

\section{Sex differences}

As mentioned previously, there are distinct sex differences in the mortality rates of atherosclerosis-related CVD in the population. In 1981, Jerome L. Sullivan presented the "iron hypothesis" that hypothesised that men and postmenopausal women were at greater risk of CVD due to higher levels of stored iron, compared to premenopausal women. ${ }^{50}$ Moreover, distinct sex differences have also been observed in the development and pathophysiology of atherosclerotic plaques. The PROSPECT study, 
evaluating plaque morphology in coronary artery disease, observed that plaques from women had less plaque rupture with smaller necrotic cores than men. ${ }^{51}$ Additionally, analysis of carotid IPH showed an age-specific sex difference in that men are more likely to have IPH at younger ages than women, albeit with increasing age postmenopause the likelihood of IPH equalises between the sexes. ${ }^{52}$ Moreover, IPH is a risk factor for the destabilisation of atherosclerotic plaque providing an increase in the availability of iron.

\section{Proteomics in atherosclerosis research}

Proteomics is the study of the entire complement of proteins expressed within an organism, tissue, or cell - both qualitatively and quantitively. ${ }^{53}$ Proteomics is to transcriptomics and genomics, as proteins are to RNA and DNA. The proteomics field has rapidly grown since the mid-1990s and is now a staple field of research used in molecular biology.

"Proteins are central to our understanding of cellular function and disease processes, and without a concerted effort in proteomics, the fruits of genomics will go unrealized" - Ian Humphery-Smith, co-founder of HUPO. ${ }^{54}$

Proteomics has been shown to be a powerful tool in the analysis of proteins within atherosclerotic lesions. A variety of proteomics techniques have been used, from conventional gel-based studies, including two-dimensional electrophoresis (2-DE) and western blot, ${ }^{55-57}$ to more complex mass spectrometry (MS) techniques, including tandem-mass spectrometry. ${ }^{58}$ Exploiting a combination of these techniques has also been used to gain a comprehensive overview. ${ }^{59,60}$ Recently, with the development of proximity extension assay proteomic chips, based on antigen-antibody reactions, have also been implemented for analysis in a large cohort to facilitate high-throughput. ${ }^{61}$ Detailed information on the type of proteomic methodologies used in this thesis are included in the Comment of Materials and Methods section. 
Different approaches have been taken for the proteomic analysis of atherosclerosis in humans. A number of studies have focussed on the tissue protein profiling of atherosclerosis, increasing the number of known proteins in plaques. ${ }^{58-60,62}$ Other studies have investigated the differences between plaque types, from early/advanced plaques and non-complicated/complicated plaques. ${ }^{57,63-65}$ Additionally, studies have analysed the plaque secretome, by culturing plaques in media, to investigate the potential of identifying circulating biomarkers that are sourced from plaques. ${ }^{66-68}$

The use of proteomics in CVD and atherosclerosis research has been increasing over the past decade. A number of studies have used proteomics to investigate sex differences and overall CVD risk, mostly from biological fluids, such as plasma/serum and urine. ${ }^{69}$ In parallel, advancements in the proteomic profiling of atherosclerotic tissue have also occurred. ${ }^{62}$ However, as aptly reviewed, studies have yet to focus on identifying sex differences in the atherosclerotic plaque tissue proteome, until "now" (Paper I). ${ }^{69}$

\section{Exercise effects on atherosclerosis}

Lack of physical activity, and the adoption of a sedentary lifestyle, is a major modifiable risk factor for the development of CVD. ${ }^{3,4}$ Physical inactivity leads to an increase in visceral fat accumulation and activation of inflammatory and oxidative stress pathways, all of which are risk factors for CVD, atherosclerosis and metabolic disorders. $^{70,} 71$ Globally, according to the

In Sweden, it is estimated that approximately $23 \%$ and $27 \%$ of adult men and women are insufficiently active, respectively. ${ }^{72}$ world health organisation (WHO), it is estimated globally that approximately $23 \%$ and $32 \%$ of adult $(18+)$ men and women are insufficiently active, respectively. ${ }^{72}$ In general, physical activity has long been accepted as beneficial to maintaining good health and has shown to be a useful tool in both primary and secondary interventions of CVD. ${ }^{73}$ Moreover, physical activity is one of the most cost-effective strategies of intervention. ${ }^{74}$ 
Exercise intervention studies rely heavily on the analytical measurements of circulating markers in the blood and the measurement of physical body parameters. Various circulating markers are implicated in disease mechanisms and physical body parameters, such as blood pressure, weight, body mass index (BMI) etc., can be used as a measure of overall health. Exercise-induced changes in circulating marker and/or physical body parameters can be indicative of potential changes in disease processes in the body.

Exercise has been shown to exert beneficial effects on molecular and cellular processes that are central in atherogenesis and plaque vulnerability, including inflammation, endothelial cell dysfunction, and macrophage foam cell formation. Exercise-induced regulation of inflammatory cytokines is a well-studied area. As comprehensively reviewed, exercise induces reductions in circulating inflammatory cytokines and chemokines, such as tumour necrosis factor- $\alpha$ (TNF- $\alpha$ ), interferon- $\gamma$ (IFN- $\gamma$ ), interleukin-6 (IL-6), MCP-1, as well as c-reactive protein (CRP), in patients with atherosclerosis-related CVD. ${ }^{75}$ Exercise is a promising therapy for endothelial cell dysfunction by promoting nitric oxide (NO) bioavailability. NO bioavailability is linked with injury to the endothelial cell layer in blood vessels at the early stage of atherogenesis and NO bioavailability is impaired with increasing levels of ROS and oxLDL. ${ }^{76}$ Macrophage foam cell formation can be indirectly reduced by the effects of exercise, which can promote the clearance of cholesterol, including LDL, to the liver. ${ }^{77}$

The type of exercise used as an intervention can also exhibit different outcomes on patient health in a trial. In general, both moderate aerobic and strength/resistance training (RT) are seen to be beneficial in reducing the circulating inflammatory profile and have been advised to alleviate CVD risk factors. ${ }^{78,79}$ However, intensive prolonged aerobic exercise can be detrimental in increasing the circulating inflammatory profile. ${ }^{80}$ The type and duration of exercise is therefore an important consideration in exercise intervention. 


\section{AIMS}

\section{Papers I \& II}

To investigate the proteomes from distinct regions of human carotid atherosclerotic plaques and identify protein alterations in relation to sex and plaque region.

\section{Paper III}

To investigate inflammation and iron metabolism in human atherosclerotic plaques and how these differ between sexes.

\section{Papers IV \& V}

To investigate if supervised resistance training amongst postmenopausal women can alter cardiovascular disease risk markers, including; body iron status, oxidative stress, lipid profiles, and inflammation, adipokine and immune markers. 


\section{COMMENTS ON MATERIALS AND METHODS}

\section{Patient cohorts}

\section{Linköping Carotid Study (Papers I-III)}

The Linköping Carotid Study is a prospective clinical pathology study in which carotid atherosclerotic plaques are collected from patients undergoing carotid endarterectomy at Linköping University Hospital. The study was approved by the Regional Ethical Review Board, Linköping, Sweden (2003-449) and all procedures were carried out in accordance with accepted guidelines. Written informed consent was obtained from all patients included in this study.

Proteomic analyses carried out in Papers I and II used carotid endarterectomy samples from 26 patients, 13 men and 13 women. In Paper I, samples from 3 men and 3 women were used for two-dimensional gel electrophoresis (2-DE) and matrix-assisted laser desorption/ionisation time-of-flight (MALDI-TOF) mass spectrometry (MS) analysis. In Papers I-III, samples from 10 men and 10 women were used for nanoliquid chromatography tandem MS (nLC-MS/MS; hereafter referred to as 'tandemMS'). In Paper III carotid endarterectomy samples from 62 consecutive patients, 39 men and 23 women, were used for immunohistochemistry (IHC) analyses.

In proteomic analyses for Papers I and II carotid endarterectomy samples were further processed to excise predefined regions of interest, including: internal control, fatty streak, plaque shoulder, plaque centre and fibrous cap (Figure 5). These intralesion biopsies were taken to reduce the effect of heterogeneity in atherosclerotic tissues. Additionally, we hypothesised that using such intra-lesion biopsies would provide insights into protein localisation, abundances, and in turn could potentially shed light on functional implications in atherogenesis and plaque vulnerability. From each patient, all four intra-lesion regions and internal control were taken from the same carotid artery. These biopsies were used for 2-DE and MALDI-TOF MS analysis, and three intra-lesion regions were used to tandem-MS analysis (internal control, fatty streak and plaque centre). 


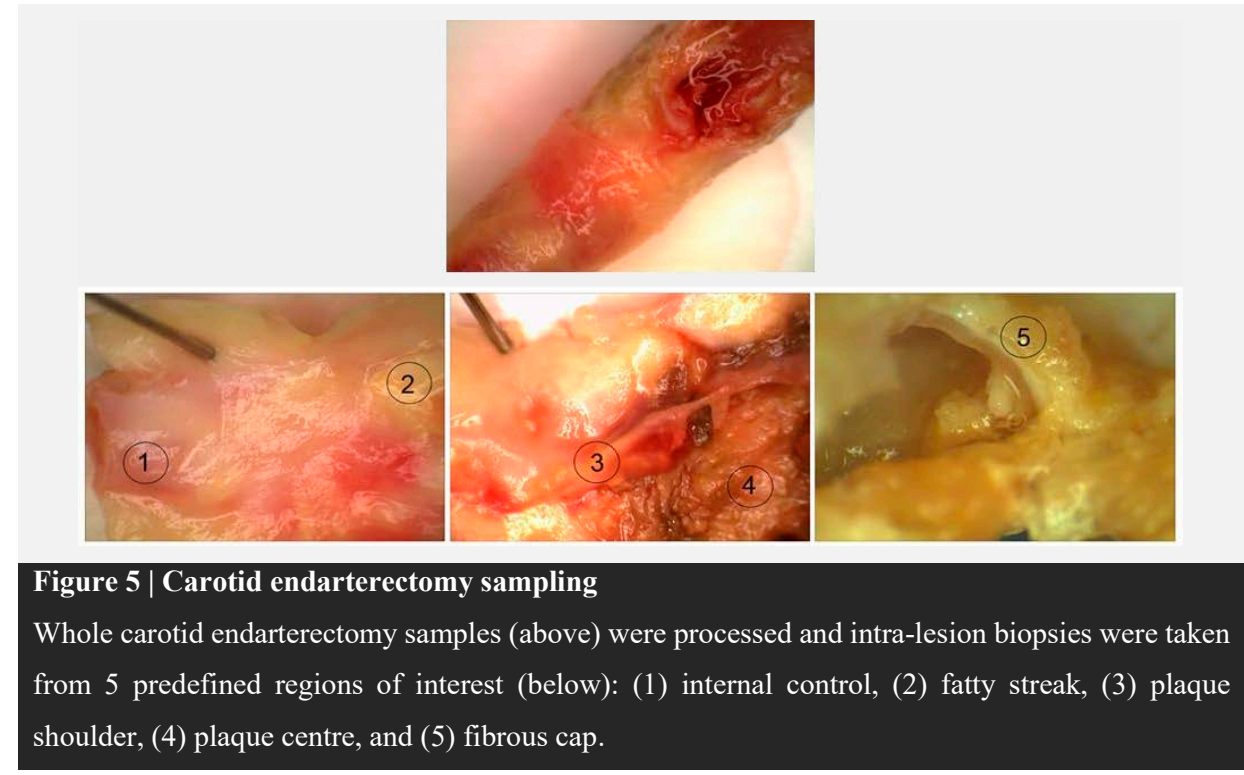

\section{Strength "Styrka" Study (Papers IV-V)}

The Strength (Swedish: "Styrka") Study is a registered clinical trial (clinicaltrials.gov identifier: NCT01987778) conducted at Linköping University Hospital, Sweden. The study was approved by the Regional Ethical Review Board, Linköping, Sweden (2013/285-31 and 2013/338-32) and all procedures were carried out in accordance with accepted guidelines. Written informed consent was obtained from all participants prior to entry to the trial.

The Strength Study is an open, parallel, randomised controlled intervention trial where healthy postmenopausal women $(\mathrm{n}=65)$ were recruited to take part in a 15 weeks exercise programme. Women were randomised to join a control group with unchanged physical activity, or a resistance training (RT) intervention group. The exercise programme was based on supervised RT targeting all major muscle groups, utilising either seated resistance machines or body-weight exercises. A full description of the trial design, inclusion- and exclusion-criteria and resistance training programme can be found in the paper by Berin, et al. ${ }^{81}$ Venous blood samples were taken at week0 and week- 15 of the trial period. Plasma was isolated from samples and stored at $-70^{\circ} \mathrm{C}$ for investigations. 


\section{Proteomics}

\section{Protein extraction (Paper I-III)}

The first step in the proteomic workflow is to obtain a protein extract that is suitable for experimentation. Protein extraction methods can be used on a wide variety of samples, including; plasma, cells, and tissues. The method of protein extraction used in Papers I-III was a liquid-phase separation using the acid guanidinium thiocyanatephenol-chloroform extraction; commonly known by the brand names TriZol (Invitrogen, UK) or TRI reagent (Sigma-Aldrich, MA, USA). This method was first developed for the extraction of RNA but is also suitable for the isolation of DNA and proteins in the same procedure. ${ }^{82}$

\section{Two-dimensional gel electrophoresis (Paper I)}

Two-dimensional gel electrophoresis (2-DE) is a method of protein separation, used prior protein identification techniques, that is widely used for proteome analyses. ${ }^{83}$ Indicative of its name, 2-DE combines separation in two dimensions; separating by isoelectric point, the $\mathrm{pH}$ where a molecule carries a net electrical charge of zero, and by molecular weight (Figure 6). The first dimension, called isoelectric focussing (IEF), uses an immobilised $\mathrm{pH}$ gradient (IPG) gel strip that is rehydrated with solution containing denatured proteins. Once electricity is applied to the strip, the proteins migrate towards their respective isoelectric points. ${ }^{84}$ The second dimension, separation by molecular weight, uses sodium dodecyl sulphate-polyacrylamide gel electrophoresis (SDS-PAGE). The IPG strips from the first dimension are transferred onto a polyacrylamide gel and subjected to an electrical current. This allows for the separation of proteins according to size, as lower molecular weight proteins will migrate through the polyacrylamide gel faster than higher molecular weight proteins. 


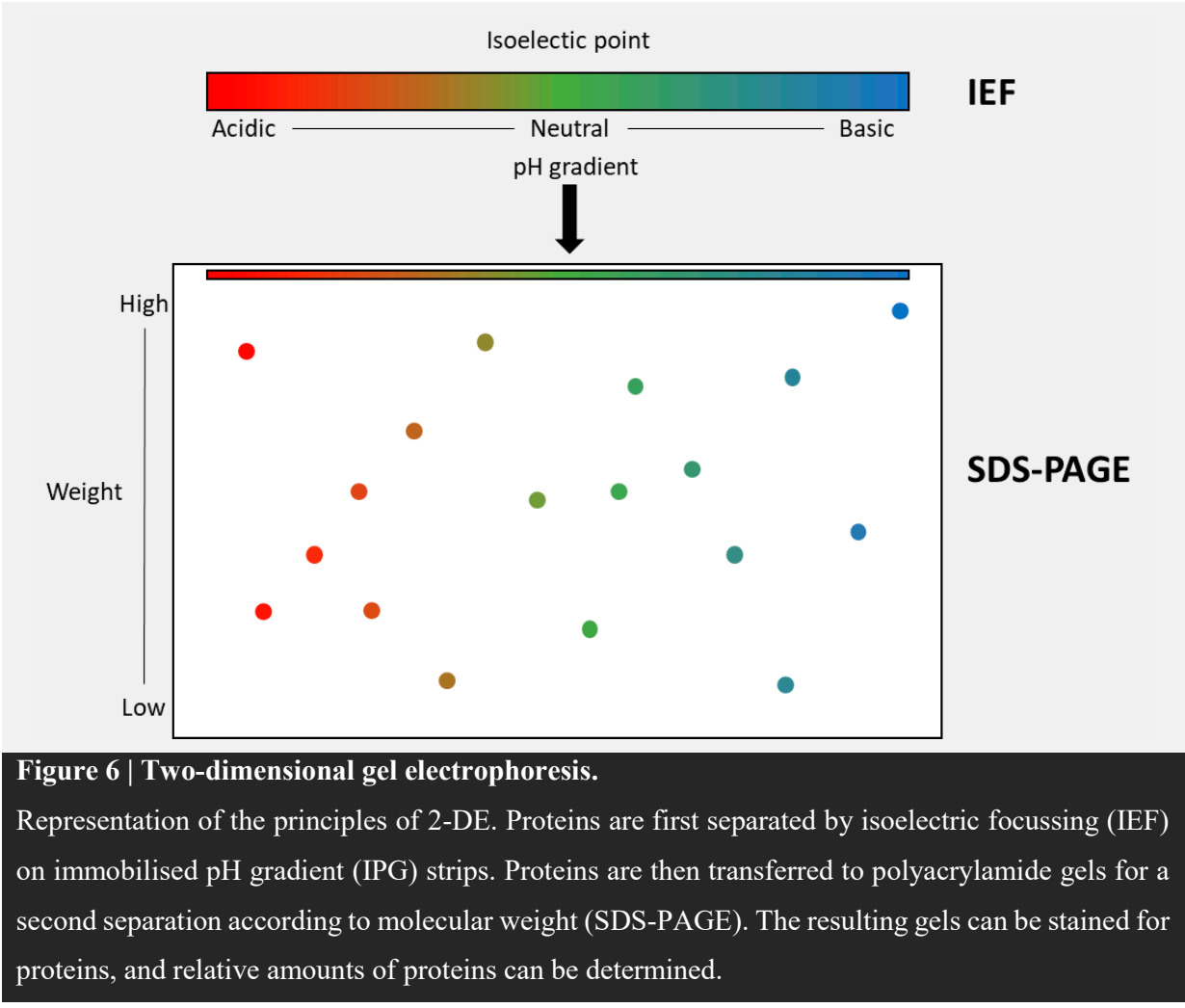

SDS-PAGE gels can then be stained to visualise the protein separation. Several staining procedures are available that vary with sensitivity, silver staining is relatively sensitive, ${ }^{85}$ whereas fluorescent stains have a broader sensitivity. ${ }^{86}$ 2-DE experiments in Paper I used the SYPRO Ruby fluorescent staining procedure. ${ }^{87}$ The fluorescent intensities of the protein staining are proportional to the relative protein abundance.

\section{MALDI-TOF mass spectrometry (Paper I)}

Matrix-assisted laser desorption/ionisation-time of flight (MALDI-TOF) mass spectrometry (MS) is a method used for protein identification and is commonly used downstream of 2-DE. The development of this technique led to the Noble Prize in Chemistry 2002 being awarded, in part, to engineer Koichi Tanaka. ${ }^{88}$ 


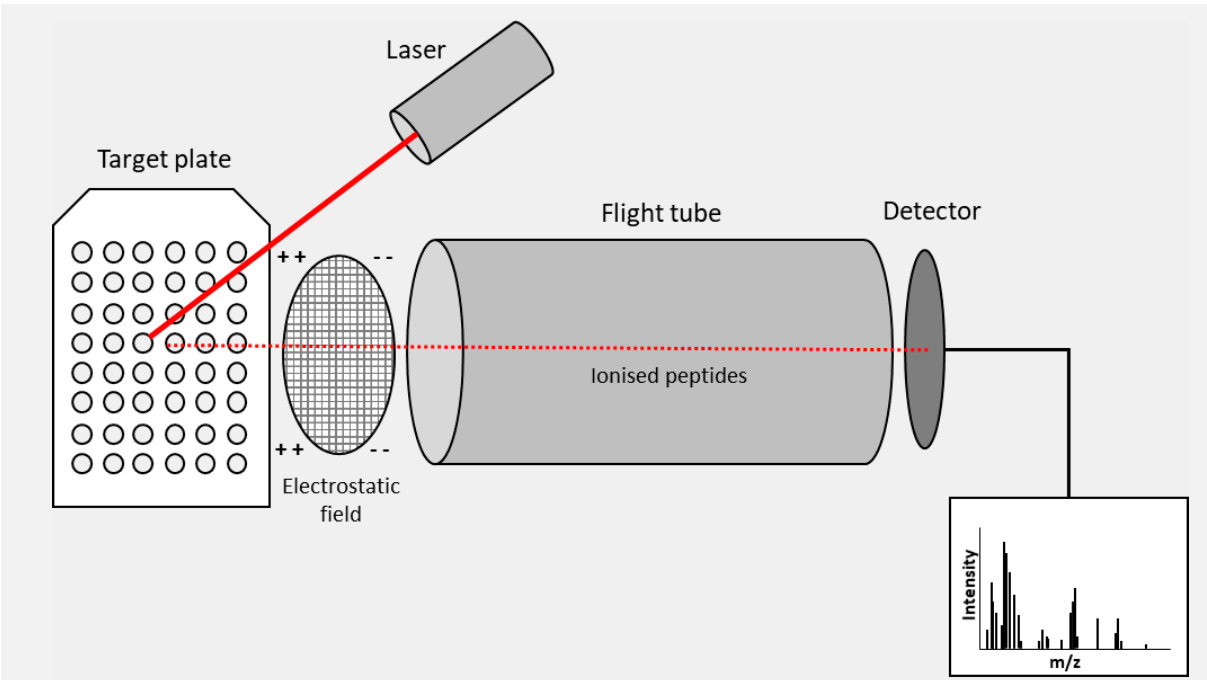

\section{Figure 7 | MALDI-TOF mass spectrometry}

Schematic representation of a MALDI-TOF mass spectrometer. Peptide-matrix samples are spotted onto the target plate. Laser pulses evaporate and ionise into the electrostatic field accelerating them through the flight tube to the detector. The travel-time from laser pulse to detector corresponded to peptide size and is used to calculate the mass-to-charge ratio $(\mathrm{m} / \mathrm{z})$.

Separated protein spots are excised from 2-DE gels, de-stained, and exposed to an endopeptidase (e.g. trypsin) to digest proteins in preparation for MS analysis. The resulting peptides are combined with an acidic matrix solution. Common matrix solutions include $\alpha$-cyano-4-hydroxycinnamic acid and 2,5-dihydroxybenzoic acid, the latter matrix performs better for low-abundant proteins from 2-DE. ${ }^{89}$ The peptidematrix mixture is then spotted onto a target plate where the mixture dries forming crystalline structures. In the mass spectrometer, these crystals are hit by a laser and absorb energy, this subsequently leads to the evaporation and ionisation of singlycharged peptides in the matrix. An electrostatic field accelerates these charged peptides through the flight tube, in a vacuum, to a detector (Figure 7). Herein, only the peptide mass can affect the travel-time, which is used to calculate the mass-to-charge ratio $(\mathrm{m} / \mathrm{z})$ that corresponds to the peptide size. ${ }^{90}$ The MALDI-TOF MS spectrum can be used to generate a peptide mass list that is subjected to database searching, called peptide-mass fingerprinting, which results in protein identification. 


\section{Tandem-mass spectrometry (Papers I-III)}

The use of nano-liquid chromatography tandem-MS (nLC-MS/MS, herein referred to as tandem-MS), was used in Papers I-III. We have specifically used a labelfree workflow that is widely used and recommended for potential biomarker discovery in proteomic studies.91, 92 The method consists of two major systems; a liquid chromatography (LC) system, and a hybrid-MS system containing both a linear ion-trap and an Orbitrap (orbital ion trap).

In preparation for tandem-MS, protein samples are reduced, alkylated, and digested with the use of dithiothreitol, iodoacetamide, and an endopeptidase (e.g. trypsin) respectively. The resulting peptide mixtures are lyophilised and reconstituted in an acidic solution, in this case $0.1 \%$ formic acid, that aides in ionisation. These samples are then loaded into the LC system in a reverse-phase LC column, which separates the peptide samples by size and hydrophobicity, via an increasing organic solvent concentration gradient. The peptides are then introduced to the hybrid-MS system via electrospray ionisation, displacing ionised peptides from a liquid to a gaseous state. The hybrid-MS system comprises of a linear-ion trap and an Orbitrap. The initial scan of peptides occurs in the Orbitrap, with high resolution, of which the most intense ions will be selected for fragmentation. These precursor ions are fragmented in the linear ion trap via collision-induced dissociation, which collides ions with an inert gas whereby the kinetic energy is converted to internal energy that fragment the amino acid backbone..$^{93}$ The fragments are then analysed according to their respective $\mathrm{m} / \mathrm{z}$, which can then be compared to the theoretical MS data.

\section{Multivariate statistical modelling (Paper II)}

Proteomics, like the other -omics methodologies, can produce large datasets from a low number of subjects. It is becoming more apparent that complex conditions and diseases do not occur from alterations in a single biomarker, but more likely the result of alterations in multiple biomarkers. Traditional univariate statistics compares changes between individual variables, assuming independence from one another, and disregarding any potential interrelationships. ${ }^{94}$ Conversely, multivariate statistical 
modelling, based on component analyses, is capable of handling interrelated variables more akin to biological systems. ${ }^{95}$ Moreover, multivariate statistical modelling is more appropriate to handle such datasets comprised of low subject-to-variable ratios, reducing the number of false positives without the loss of statistical power. ${ }^{95}$

An example of a multivariate model is orthogonal partial least squaresdiscriminant analysis (OPLS-DA) (Paper II), which can be used to predict which variables are responsible for discrimination between two predefined groups. OPLS-DA indicates what variables drive the differences between the groups, with each variable being assigned a 'variable influence on projection' (VIP) value. The greater the VIP value, the greater the influence on the group discrimination. ${ }^{95,} 96$ These types of multivariate models are useful in reducing such large datasets to so-called biomarker "fingerprints" that can be further explored in more detail..$^{96}$

\section{Immunohistochemistry (Papers I \& III)}

Immunohistochemistry (IHC) is a method to visualise the distribution of specified proteins within a tissue. IHC is based on an antigen-antibody reaction that can produce a visible staining on a tissue section (Figure 8). In principle, a primary antibody for a specific antigen of interest is used, then a secondary antibody conjugated to an enzyme for chromogen conversion. A commonly used enzyme is horse-radish peroxidase (HRP) that catalyses the oxidation of 3',3'-diaminobenzidine (DAB), a common chromogen, to produce a brown pigmentation. ${ }^{97}$ The resulting pigmentation can be examined via light microscopy and images digitised. For quantification of IHC, a percentage of total pixel area can be calculated by recording both positive- and negative immunostained pixels for each image. All histological samples should be assessed by at least two observers, who are blinded to the clinical characteristics and classifications of the samples. 


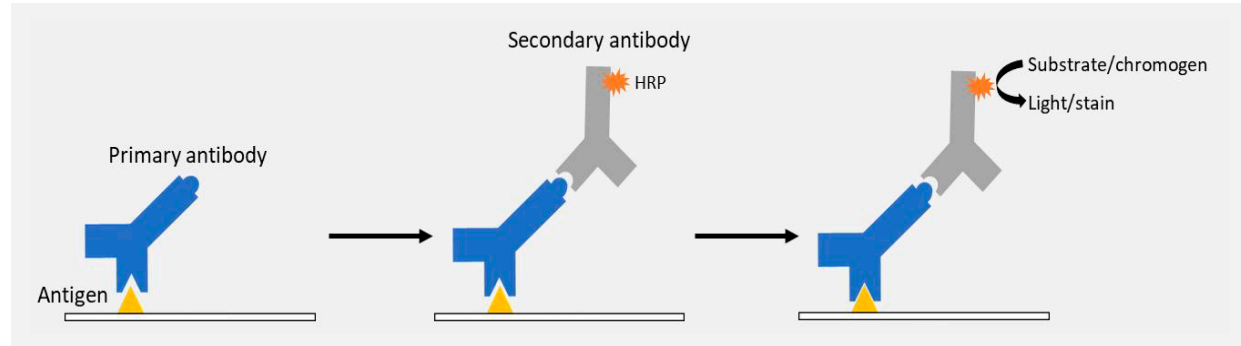

Figure 8 | Antigen-antibody reaction

Sample antigens are immobilised to a solid support, or present on a tissue sections, and are exposed to a specific primary antibody. A complementary horseradish peroxidase (HRP)-conjugated secondary antibody is then incubated to bind. The HRP enzyme is used to catalyse a substrate or chromogen to produce a light or staining that can be measured.

\section{Western blot (Paper II)}

Western blot is comparable to the second-dimension separation in the 2-DE methodology with the inclusion of an antigen-antibody reaction (Figure 8).$^{98}$ Protein samples are denatured, and negatively charged, via boiling in an SDS-containing running buffer. The samples are then separated by molecular weight by SDS-PAGE and transferred to a membrane for antibody probing. Membranes are blocked, with buffers containing non-fat milk or bovine serum albumin, to prevent non-specific binding prior incubation with the primary antibody. As with the previously described IHC methodology, the principle of the antigen-antibody reaction is the same; incubation with the primary antibody, and then incubation with a secondary antibody conjugated to HRP (Figure 8). In Western blot, HRP catalyses the oxidation of luminol in enhanced chemiluminescence solution, the result of which emits light that can be imaged using a charged coupled device (CCD) camera. ${ }^{99}$ Western blot, much like 2-DE, is merely a semi-quantitative method in that relative values can be deduced from measures of optical density ${ }^{98}$ Herein, however, this method was used only as a qualitative measure of protein expression. 


\section{Enzyme-linked immunosorbent assay (Papers IV \& V)}

As with the prior methods, IHC and Western blot, enzyme-linked immunosorbent assay (ELISA) runs on the premise of an antigen-antibody reaction. ELISA can be run on protein extracts and/or biological fluids, run within a microtiter plate, and is based on colourimetry. Multiple types of ELISA methods exist, including: direct, sandwich, reverse, indirect, and competitive, the latter two types were used in Papers IV and V.

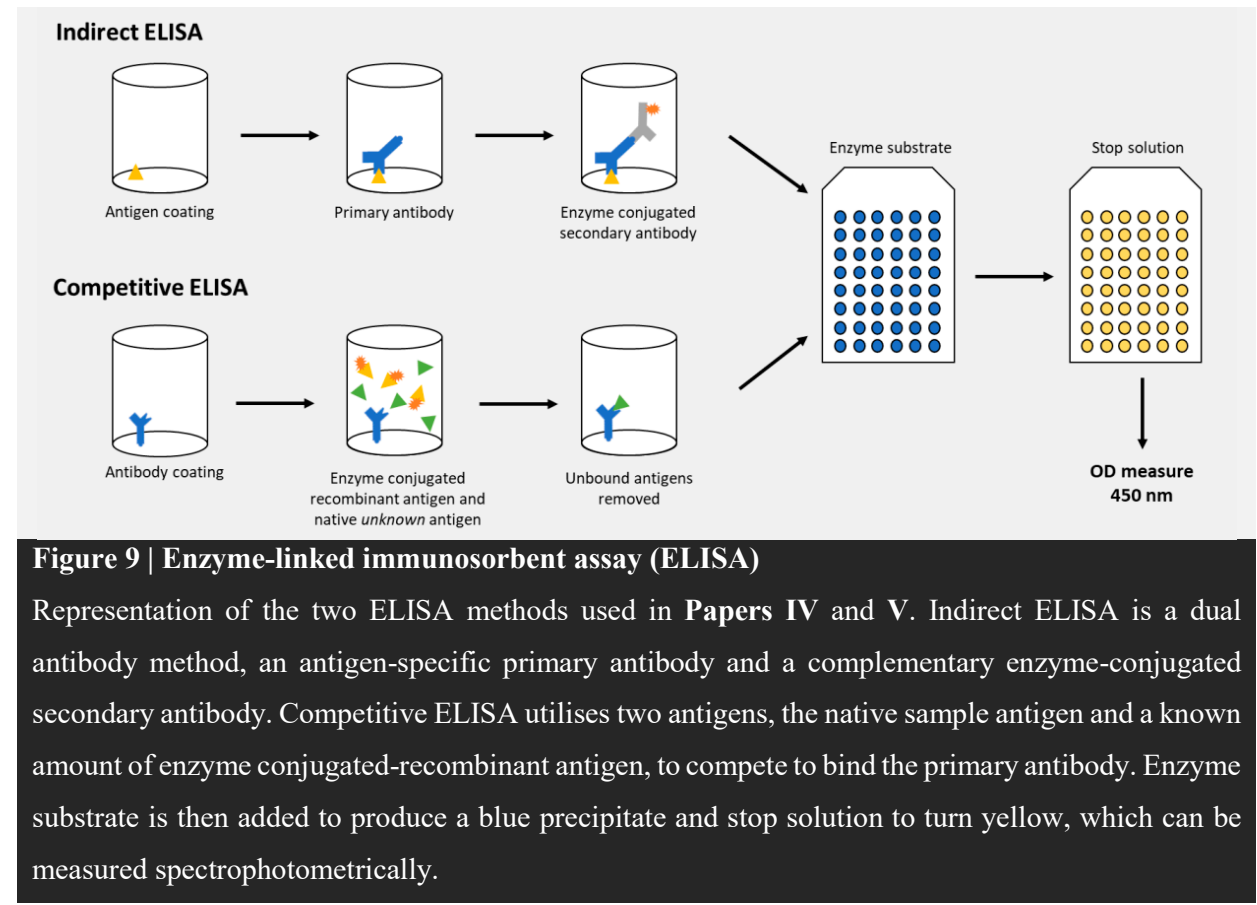

The indirect ELISA method is based on the more conventional antibody-antigen reaction, as previously described in the Western blot method. Antigens, from standards and samples, are coated onto the microtiter wells. A specified primary antibody is added, followed by the addition of an enzyme-conjugated secondary antibody (Figure 9). Competitive ELISA, as the name suggests, is based on a competitive antigenantibody reaction. Initially, the microtiter plate is coated with the specified primary antibody. Then the sample, with the native antigen of interest, and enzyme-conjugated 
recombinant antigen, the competing antigen, are added to the microtiter wells. As a known amount of recombinant antigen is added to each microtiter well, the amount of native antigen in the sample will determine the binding ratio between native and recombinant antigen. After incubation, all unbound antigens are washed away. To measure the level of antigen-antibody complexes in microtiter wells an enzyme substrate is added, 3,3'5,5'-tetramethylbenzidine (TMB) is used for HRP enzymeconjugates, the results of which produces a blue coloured precipitate. The enzymesubstrate reaction is stopped with the addition of an acidic stop solution that turns the blue precipitate yellow, which can be measured spectrophotometrically at $450 \mathrm{~nm}$ (Figure 9). ${ }^{100}$ The light absorbance, measured in optical density values, is equivalent to the concentration of the molecule of interest and can be calculated from a known standard curve.

\section{Multiplex bead array (Paper V)}

Multiplex bead array, commercially and commonly referred to as Luminex, is an immunoassay method with similar reaction principles to ELISA methodology. The major difference is that Luminex is a bead-based immunoassay, that can simultaneously measure multiple analytes in a single sample. The principle is that capture antibodies are coated to either polystyrene or magnetic beads that are dyed to distinct spectral regions. As each set of beads is uniquely dyed, different beads can be coated with different antibodies and mixed together to add to each microtiter well, thus allowing for multiple analytes to be measured simultaneously. To analyse the antibody-conjugated beads that have bound antigens, a biotin-conjugated secondary antibody is added. Streptavidin-phycoerythrin is used to detect biotinylated antibody complexes, which when run through a dual-laser detection system is excited and induces a light emission. The concentration of analytes can be calculated using a standard curve of known concentrations. 


\section{Statistical analyses (Papers I-V)}

The Shapiro-Wilk test (Papers I-V) is a test of normality to analyse distribution amongst continuous variables. Shapiro-Wilk test was used as a prerequisite to other statistical tests used for continuous variables. The null hypothesis for the Shapiro-Wilk test is that data are normally distributed. Should the p-value be less than the chosen alpha level, e.g. 0.05, then the null hypothesis is rejected, and the data are non-normally distributed. Non-parametric tests, that do not assume normal distribution, are therefore preferred for further analyses.

Mann-Whitney $U$ test (Papers I-V), Wilcoxon signed rank test (Papers IV-V), and Spearman's rank correlation (Papers III-IV) are all examples of non-parametric statistical analyses used within this thesis. Mann-Whitney $U$ and Wilcoxon signed rank tests both compare the differences in distribution between two samples, evaluating differences between independent or paired samples, respectively. Spearman's rank correlation is used to assess the relationship between the rankings of two variables within a sample set.

Chi-squared test (Papers I and III) is a statistical analysis applied to categorical/nominal variables. Chi-squared is used to evaluate if differences between variables occur by chance or not. 


\section{RESULTS AND DISCUSSION}

This section will present results and discuss them from Papers I-V that build the foundation of this thesis. Herein, only selected results are highlighted, complete results and discussions can be found in the original papers.

\section{"Deconstructing" the atheroma proteome (Paper I)}

The impact of plaque heterogeneity on the atheroma proteome has yet to be fully understood. Thus, in Paper I, one aim was to increase the amount of information obtained from proteomic analysis by attempting to reduce the effect of plaque heterogeneity. Deconstructing the carotid atheroma, by taking intraplaque biopsies, and analysing them separately allowed for more information to be obtained from proteomic analyses - as established in the 2-DE protein mapping presented in Paper I. The sampling method allowed for the mapping of 15 proteins (Table 1 and Figure 10) that had not previously been mapped before, by 2-DE and MS, in comparison to previous protein maps of carotid atherosclerotic plaques. ${ }^{55,59,60,62,101,102}$

\section{Table 1 | Newly mapped proteins in relation to carotid atherosclerotic plaque. \\ Following a literature review of previous studies utilising 2-DE/MS on carotid atherosclerotic \\ lesions, it was found that 15 protein identities had not previously been reported.}

\begin{tabular}{lll}
\hline Spot No. & Protein name & UniProt Accession \\
& & No. \\
\hline 21 & Serpin B12 & Q96P63 \\
23 & EH domain-containing protein 4 & Q9H223 \\
24 & Procollagen C-endopeptidase enhancer 1 & Q15113 \\
$33-36$ & Fibrinogen beta chain fragment & D3DP13 \\
$38-42$ & Biglycan & P21810 \\
$49-51,61$ & Rab-39 & Q14964 \\
56 & ADP-ribosylation factor-like protein 15 & Q9NXU5 \\
60 & IGK@ protein & Q6PJF2 \\
63,84 & Rab-35 & Q15286 \\
64 & Synaptophysin-like protein 2 & Q5VXT5 \\
$65-66$ & Hepatoma-derived growth factor & P51858 \\
85 & Calmodulin & P62158 \\
88 & SH3 domain-binding glutamic acid-rich-like protein & O75368 \\
90 & Synoviolin & E9PN88 \\
91 & Protein S100-A11 & P31949 \\
\hline
\end{tabular}




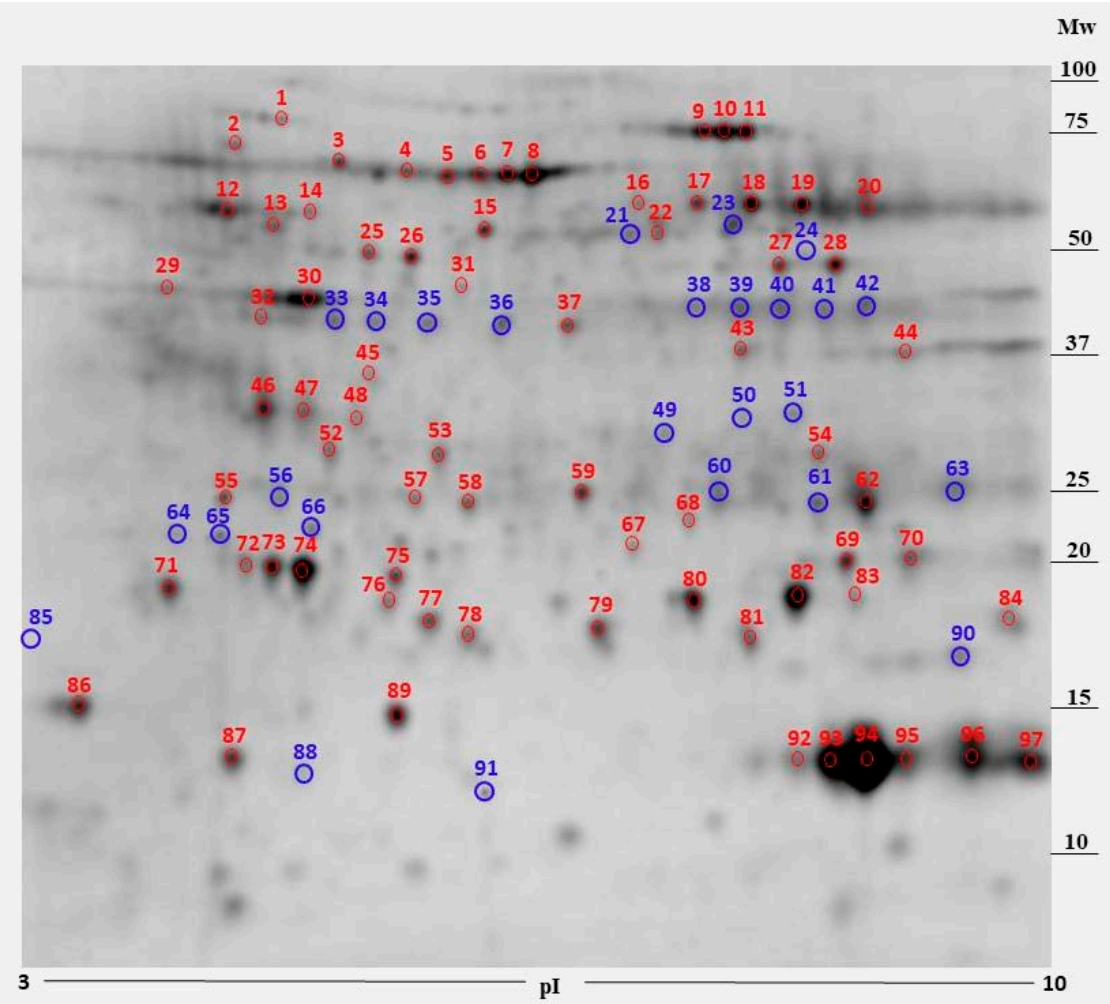

Figure 10 | Newly mapped proteins in a 2-DE protein map of carotid atherosclerosis.

2-DE protein map of carotid atherosclerotic plaque. All marked spots were identified by MALDI-

TOF MS (Paper I), and blue spots represent newly mapped proteins in comparison to previous 2-

DE protein maps of carotid atherosclerotic plaque. $\mathrm{Mw}$ - molecular weight; $\mathrm{pI}$ - isoelectric point.

This method of sampling, and 2-DE/MS analysis, allowed us to better characterise the atheroma proteome. The ability to localise proteins, and abundances, to specific areas in the atherosclerotic lesions can shed light on functional implications in atherogenesis and plaque vulnerability. From the $2-\mathrm{DE} / \mathrm{MS}$, a total of 18 proteins were found with significantly differed abundances when comparing the internal control region to each of the four plaque regions (fatty streak, plaque shoulder, plaque centre, fibrous cap). As we had compiled this data from both men and women, we proceeded to breakdown this data further to identify if these differed protein abundances were generalised across sexes, or if any showed sex specificity (to be discussed in the next section). From a generalised viewpoint, nine proteins displayed differed abundances 
consistently in specific atheroma regions, irrespective of sex, and were termed 'site-specific'. Sitespecific alterations were found predominantly in the plaque shoulder and plaque centre regions, with nine proteins showing a significant reduction in abundance when comparing the internal control to the plaque shoulder/centre regions (Figure 11).

Many of these proteins have functions involved with ECM remodelling and SMC function. The reduced abundance of mimecan and increased abundance of
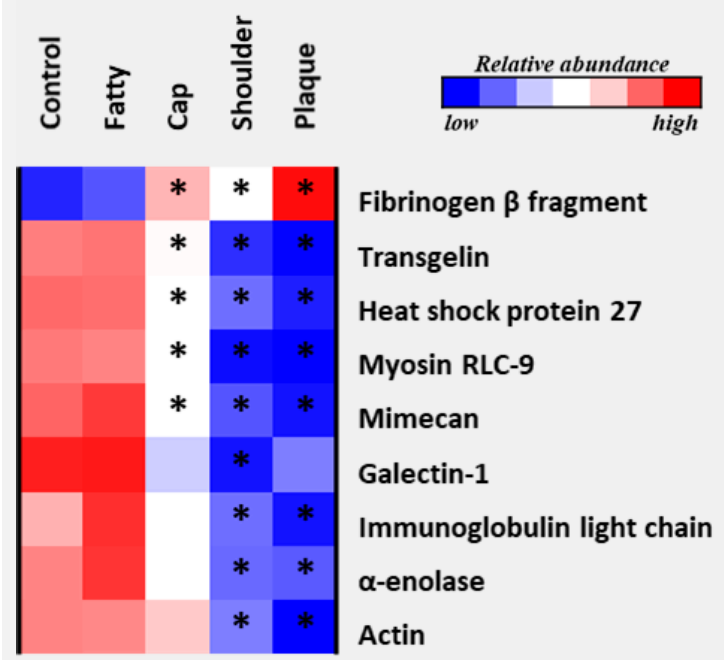

Figure 11 | Site-specific protein alterations in carotid atheroma.

Heat map depicting the differential protein abundance of nine proteins in distinct regions of atheroma from six carotid endarterectomy samples (equal sex ratio). The colour scale represents the relative abundance per protein, with red indicating high abundance through to blue indicating low abundance.

fibrinogen $\beta$ fragment is indicative of ECM remodelling in the plaque shoulder and plaque centre regions. Mimecan functions to regulate collagen fibril growth and organisation, thus dysregulated mimecan can lead to a lack of adequate ECM formation. ${ }^{103}$ Fibrinogen has a major role in blood coagulation, once cleaved to fibrin by thrombin (Figure 4), however, it can also bind a number of growth factors, e.g. fibroblast growth factor and vascular endothelial growth factor, making it an important factor in vascular ECM physiology. ${ }^{104}$ Proteomic analysis has previously identified fibrinogen fragments in atheroma, ${ }^{57}$ which can be an indicator of fibrinolysis in advanced lesions. Reduced abundances of actin, transgelin, and heat shock protein 27 (hsp- $\beta 1$ ) were present in the atheroma regions and all have described functions in vascular SMC function. Actin cytoplasmic 1 (beta-actin), the specific actin type identified in this study, is required for actin filament formation in the cytoskeleton and cell motility in vascular SMC. ${ }^{105}$ LDL present in the intima during atherosclerosis 
induces the dephosphorylation of heat shock protein 27 from actin, inhibiting actin polymerisation. ${ }^{106}$ Additionally, actin-binding protein transgelin is known to be downregulated in atherosclerosis, ${ }^{107}$ and is an early marker for SMC differentiation and repressor of MMP-9. ${ }^{108}$ Taken together these results may indicate that in advanced atheroma regions there is an increased level of ECM remodelling and degradation, reduced SMC migration, and SMC dysfunction - which can all contribute to plaque vulnerability.

Overall, the method to reduce the impact of tissue heterogeneity in atherosclerotic lesions, developed in Paper I, was successful. This result provided the basis to expand the study utilising a MS methodology with greater sensitivity: tandemMS. Results of the expanded tandem-MS were, in part, used to validate the 2-DE/MS results in Paper I, however, the majority of this investigation results are presented in Papers II and III - from a sex difference perspective. To streamline the project and increase the number of samples that could be analysed, the tandem-MS investigation only used intraplaque biopsies from three regions; internal control, fatty streak and plaque core. These regions were selected because the internal control is needed to control for individual variation, the fatty streak is a 'representation' of early atherogenesis, and the plaque core had the majority of altered protein abundances - as seen in the results from Paper I. The fibrous cap was omitted because not all atherosclerotic plaques contain a large enough fibrous cap for analysis and the plaque shoulder was omitted as the patterns of altered protein abundances were similar to that of the plaque core.

\section{Sex differences in the atherosclerosis}

In Paper I, statistical comparisons were performed comparing each atheroma region to the internal control region to identify proteins with altered abundance. In this paper we first observed sex differences in proteins that were significantly altered in atheroma regions. Proteins observed to only show significant alterations in one sex were deemed 'sex-specific' ('gender-specific' in Paper I). In atheroma from men both cathepsin D and ferritin light chain showed sex-specific alterations, and in atheroma 
from women apolipoprotein (apo) A-IV, transthyretin, ferritin light chain, and heat shock cognate $71 \mathrm{kDa}$ showed sex-specific alterations. Interestingly, both sexes showed sex-specific alterations in ferritin light chain, however, the abundances were opposing between sexes in all lesion regions, with an opposing significant increase and decrease in the fibrous cap of men and women, respectively.

These observations provided the motivation to investigate sexual dimorphism in the atheroma proteome further. Paper II was focussed specifically on sex differences in the atheroma proteome, and Paper III investigates pathophysiological differences, specifically inflammation and iron metabolism, in atherosclerosis.

\section{Proteomic perspective (Paper II)}

Paper II focussed solely on revealing the differences in the atheroma proteome between men and women, utilising tandem-MS and multivariate statistical modelling. Tandem-MS analyses of the distinct atheroma regions identified more than 1000 unique proteins per biopsy protein extract. Having analysed samples from 10 men and 10 women, with three region biopsies each, this resulted in a data matrix of over 60,000 data points. To appropriately analyse such a dataset, with a low subject-to-variable ratio, multivariate statistical

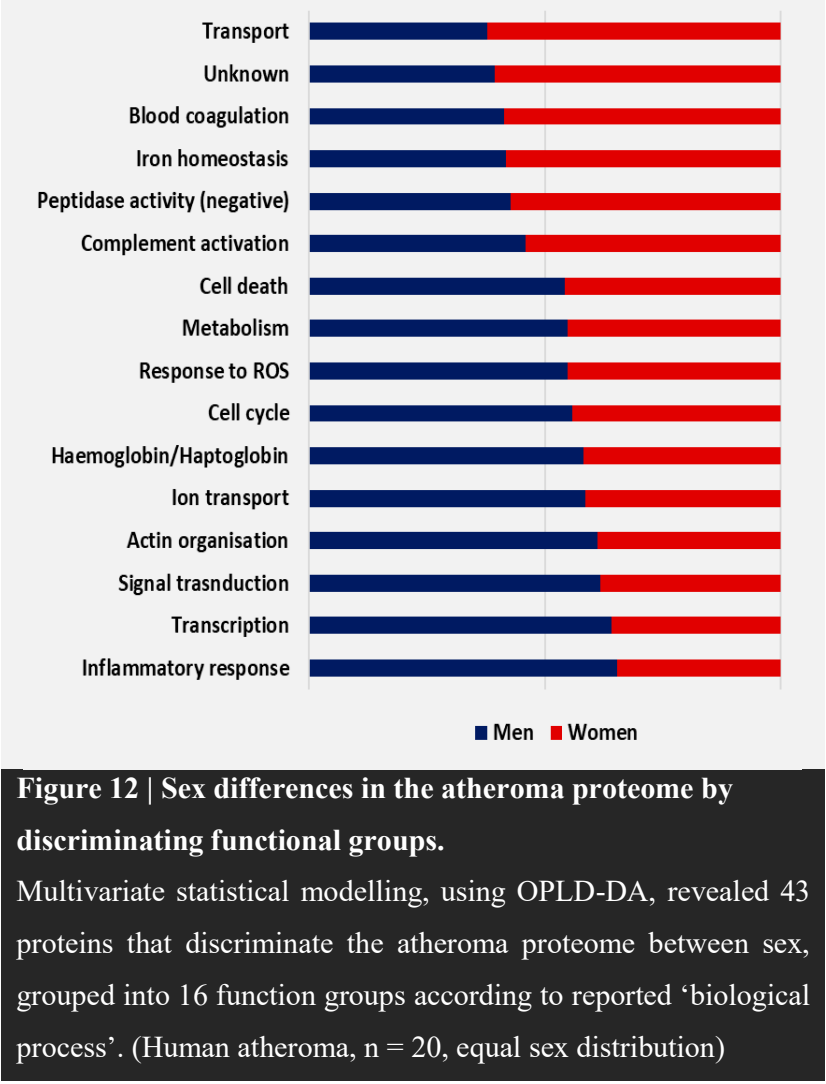



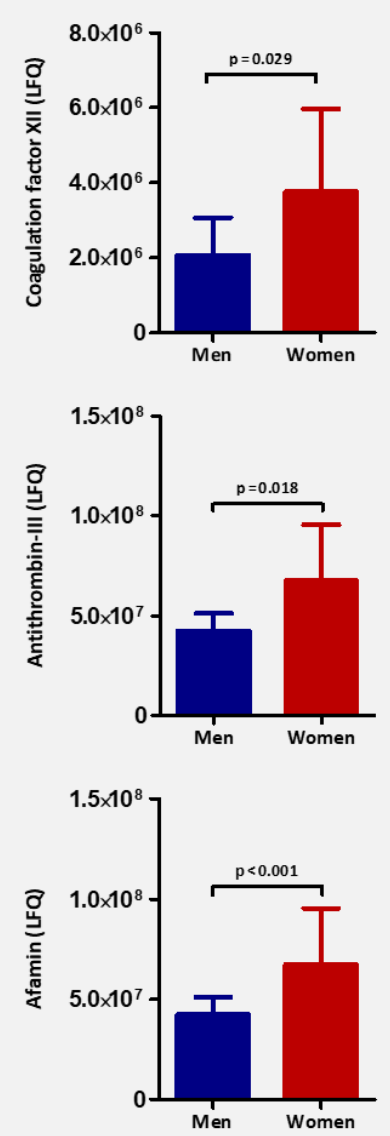

Figure 13 | Proteins with

significant altered abundances

between sexes.

Conservative univariate statistical analysis revealed three proteins that show an overall significant altered expression between carotid atheroma from men $(\mathrm{n}=10)$ and women $(\mathrm{n}=$ 10). Bonferroni adjusted p-values are used. LFQ - label-free quantification. (Data mean $\pm \mathrm{SD})$. modelling, in the form of OPLS-DA, was implemented with the categorical variables defined as 'men' and 'women'. Multivariate statistical modelling revealed 43 proteins that discriminated the atheroma proteome between men and women, these proteins were then grouped in 16 functional groups based on the reported 'biological process' from the UniProt consortium database (Figure 12).

To further filter the sex differences in the atheroma proteome, conventional univariate statistics was employed on the remaining 43 proteins. This was performed to see if the individual proteins significantly differed between sexes on their own, without taking co-variance into account. This additional filter resulted in 18 individual proteins showing significantly altered abundances between sexes, including proteins in the following functional groups: blood coagulation, cell cycle, complement activation, inflammatory response, iron homeostasis, peptidase activity (negative), response to ROS, transcription, transport, and unknown. Furthermore, upon p-value correction for multiple comparisons, using Bonferroni adjustment, three proteins retained significance with a greater abundance present in the atheroma from women; blood coagulation proteins coagulation factor XII (FXII) and antithrombin-III (AT-III), and transport protein afamin (Figure 13).

As with Paper I, the data obtained was from distinct atheroma regions, and with that, we wanted to see the sex-discriminating proteins had any atheroma region 
differences. Thus, univariate statistics was used to compare the matched atheroma regions between men and women. The results of this analysis showed that 10 proteins, from five functional groups, also displayed significant differences in abundance between specific atheroma regions (Figure 14). The majority of atheroma regional differences between sexes were found in the plaque centre region, eight proteins, and lesser so in the internal control, four proteins, and fatty streak, only afamin. FXII, ATIII and afamin showed significant differences in more than one region site, with all showing an increase in abundance in atheroma regions from women (Figure 14).
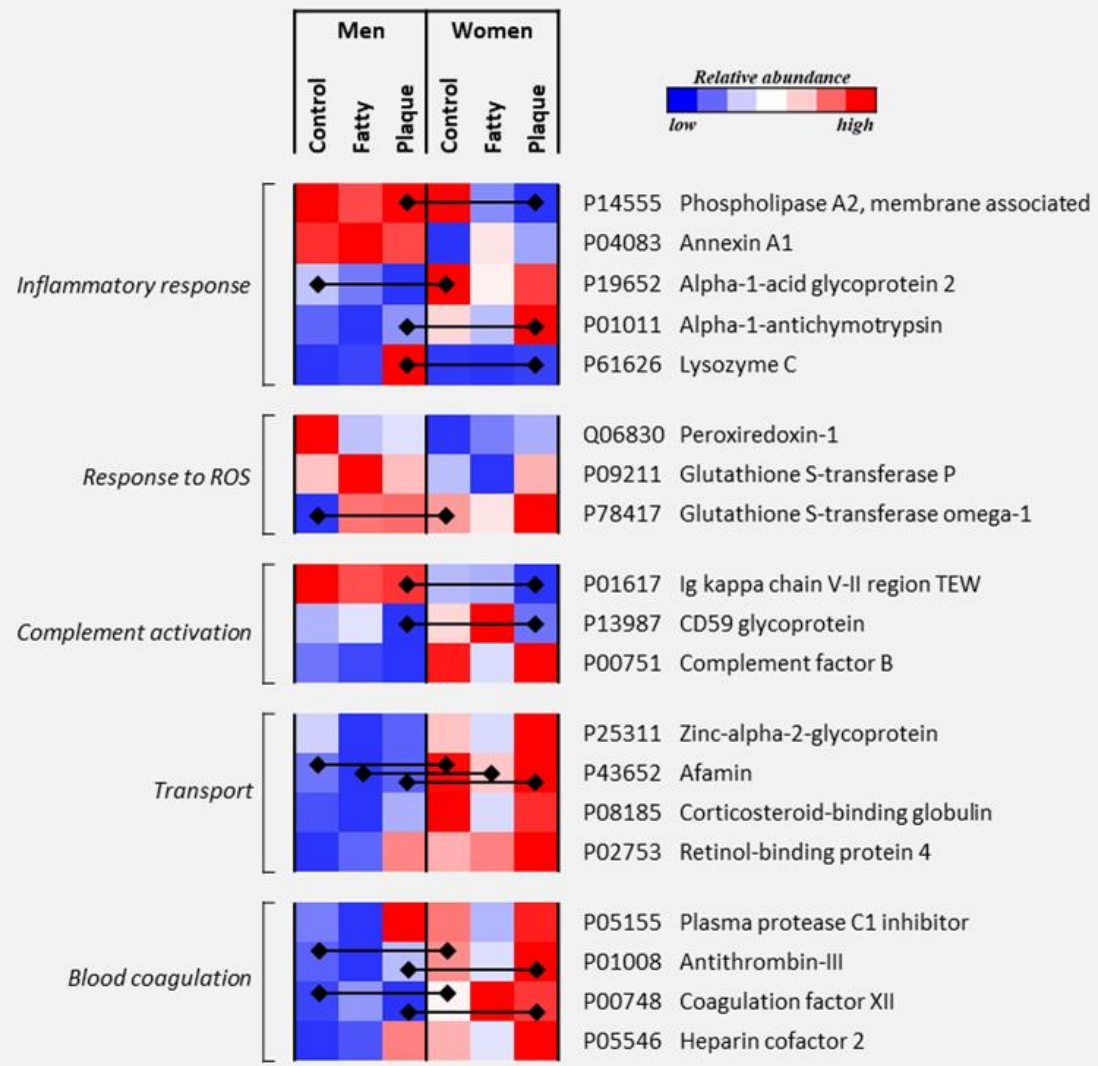

Figure 14 | Sex-discriminant proteins with significantly altered abundances between matched atheroma regions.

Heat map depicting the five functional groups with proteins that show significantly altered abundances in one or more regions from carotid atheroma ( $n=20$, equal sex). Colour scale represents relative abundance per protein, with blue representing low abundance through to red representing high abundance. Bars represent a significant difference, $\mathrm{p}<0.05$, between matched atheroma regions. 
To summarise, and select some of the key results, when looking at sex differences in carotid atheroma: the increases of FXII, AT-III and afamin are the most prominent differences in the atheroma from women, alongside the increases in inflammatory response proteins, phospholipase A2 membrane associated (sPLA2-IIA) and lysozyme $\mathrm{C}$, in the atheroma from men.

FXII and AT-III, a serine protease and serine protease inhibitor (serpin), respectively, both function in the blood coagulation system and are found at increased abundances in atheroma from women. Interestingly, these two proteins have somewhat opposing functions, with FXII being associated with plaques with greater inflammatory cytokine release and susceptibility to plaque instability, ${ }^{109}$ and AT-III inhibiting thrombin and aiding plaque stability. ${ }^{110}$ Previously, in a large cohort study, AT-III has been observed at increased levels in women. ${ }^{111}$ The answers as to whether the increased abundance in women is beneficial in aiding plaque stability, or not, may lie in the disruption of the clotting cascade at varying levels. FXII conversion is at the beginning of the intrinsic pathway of the coagulation cascade, whereas thrombin lies at the end of the coagulation cascade and converts fibrinogen to fibrin to create the thrombus (Figure 4). Inhibition of thrombin by AT-III, and also heparin cofactor 2 , can inhibit thrombus formation. ${ }^{110}$ This 'stop' at the end of the coagulation cascade may inadvertently cause the increased abundance of FXII at the beginning of the cascade, however, more indepth studies are required to investigate this and the effects on other factors in the coagulation cascade in relation to thrombosis and atherosclerosis. It must be noted that a number of serpins have been identified in this study with overall increased abundances in atheroma from women, including; alpha-1-antichymotrypsin (serpin A3), AT-III (serpin $\mathrm{C} 1$ ), plasma protease $\mathrm{C} 1$ inhibitor (serpin $\mathrm{G} 1$ ), heparin cofactor 2 (serpin D1), and corticosteroid-binding globulin (serpin A6).

Afamin is the fourth member of the albumin gene family and is a vitamin-E transport protein. ${ }^{112}$ The majority of vitamin $\mathrm{E}$ transport takes place in the lipoprotein system, wherein a proportion of afamin is associated to HDL. ${ }^{113} \mathrm{HDL}$ is commonly referred to as the 'good' cholesterol and increased levels of afamin may be an indication of higher levels of HDL in the atheroma from women. 
Although no conservative significant increases were found in the atheroma from men, there were a number of proteins with more liberal significance. Amongst these, two inflammatory response proteins showed significant increases between sexes, overall and with regional differences in the plaque centre region; sPLA 2 -IIA and lysozyme $C$. It should come to no surprise that proteins related to inflammation would become a focus in a study related to atherosclerosis and indeed, inflammatory response proteins were the most discriminant functional group for the atheroma from men (Figure 12). These have both been attributed to atherosclerotic disease. SPLA $_{2}$-IIA functions to hydrolyse LDL in the vascular wall promoting foam cell formation and inflammation. ${ }^{114}$ A similar protein, lipoprotein-phospholipase A2, also display sexual dimorphism with increased abundance, also stimulating inflammation, in atheroma from men. ${ }^{115}$ Lysozyme $\mathrm{C}$ has been proposed as a possible plasma biomarker for atherosclerotic disease, as the plasma levels are correlated with disease severity. ${ }^{116}$ Conversely to afamin, lysozyme $\mathrm{C}$ has been found associated with LDL, the 'bad' cholesterol, at increased levels in patients with metabolic syndrome. ${ }^{117}$ Thus, increased lysozyme $\mathrm{C}$ could be an indication of higher levels of LDL in the atheroma from men.

\section{Pathophysiology perspective (Paper III)}

Paper III investigated the sex differences in carotid atheroma in relation to inflammation and iron metabolism, complimented with relevant results from the multivariate proteomic analyses in Paper II. The primary results from this study were based on serum analyses and IHC analyses of sections of human carotid atheroma from men and women having undergone carotid endarterectomy. Carotid atheromas from 62 patients were divided into two groups by sex, men $(n=39)$ and women $(n=23)$. To complement these findings results from two discriminating protein groups, iron homeostasis and haemoglobin/haptoglobin, were also presented.

Haemoglobin $(\mathrm{Hb})$, the iron-containing oxygen transport protein in red blood cells, at high blood concentrations has been identified as a risk factor for major atherosclerotic events. ${ }^{118}$ Herein, serum analysis revealed that men had significantly higher levels of $\mathrm{Hb}$ than women (Figure 15A). Hb levels were also significantly associated with men, independent of potential confounders, such as age, hypertension, 
statin therapy, diabetes, and smoking. Increased abundances of $\mathrm{Hb}$, subunits $-\alpha$ and $-\beta$, were also observed in the atheroma from men on proteomic analysis (Figure 15B). This association of $\mathrm{Hb}$ and male sex led us to categorise the patients by serum $\mathrm{Hb}$ levels, using the mean serum $\mathrm{Hb}$ level as a cut-off, into the high $(\mathrm{Hb}>140 \mathrm{~g} / \mathrm{L})$ or low $(\mathrm{Hb} \leq$ $140 \mathrm{~g} / \mathrm{L})$ groups. After categorisation, it was found that the majority of men had high levels of $\mathrm{Hb}$ (Figure 15C), that high $\mathrm{Hb}$ levels were indicative of high-risk plaques with rupture (Type 3; Figure 15E), and that these high-risk plaques were more commonly found in men (Figure 15D). Extracellular and/or serum-free $\mathrm{Hb}$ can contribute to atherosclerosis, being a source of labile iron upon its breakdown in the vessel wall.

A

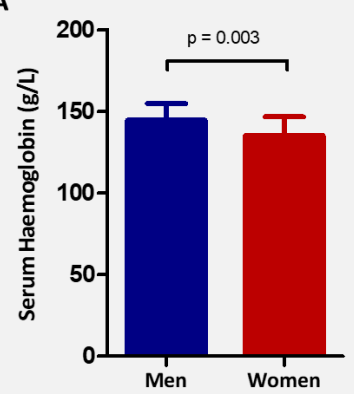

B

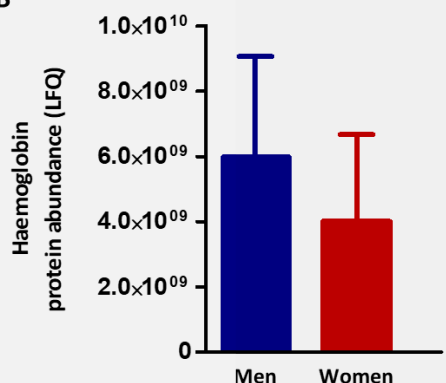

C

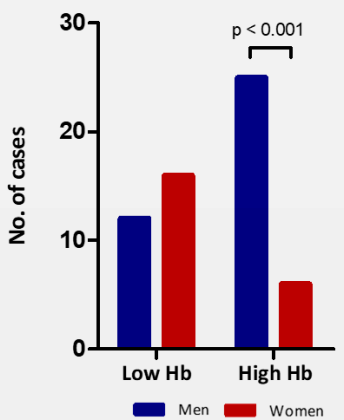

D

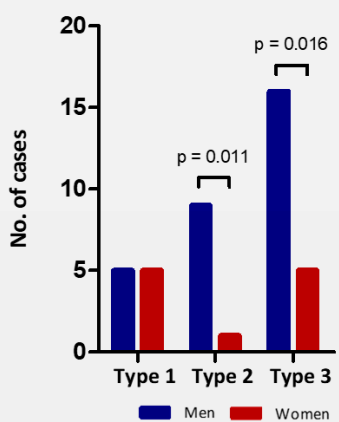

E

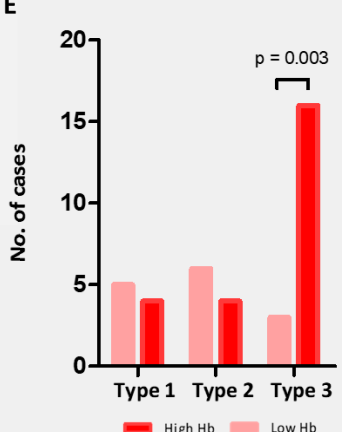

Figure 15 | Men have significantly greater amounts of haemoglobin, which is associated with more severe plaques.

(A) Men have significantly higher levels of haemoglobin $(\mathrm{Hb})$ in the serum than women $(n=39 / 23$ men/women) (Data mean \pm SD). (B) Protein abundance of $\mathrm{Hb}$, subunits $-\alpha$ and $-\beta$ combined, were non-significantly increased in atheroma from men. $(n=20$, equal sex distribution) (Data mean $\pm \mathrm{SD})$; (C) Significantly more men presented with high levels of serum $\mathrm{Hb}(>140 \mathrm{~g} / \mathrm{L}$ ) than women (high/low Hb: $n=25 / 12$ men, $n=5 / 16$ women); (D) Significantly more men presented with more advanced plaque (type 2 and 3 ) than women (type 1/2/3: $n=5 / 9 / 16$ men, $n=5 / 1 / 5$ women); (E) Type 3 plaques are associated with high serum $\mathrm{Hb}(>140 \mathrm{~g} / \mathrm{L}$ ) (type 1/2/3: $\mathrm{n}=4 / 4 / 16$ with high $\mathrm{Hb}, \mathrm{n}=5 / 6 / 4$ with low $\mathrm{Hb}$ ). 
$\mathrm{Hb}$, as well as the $\mathrm{Hb}$-scavenger proteins haptoglobin, have also been shown to associate with HDL in patients with coronary heart disease but not in healthy individuals. ${ }^{119}$ These associations with HDL were observed to impair normal HDL function and promote a more proinflammatory nature. ${ }^{119}$ Another haem-scavenger protein hemopexin, is thought to be antiatherogenic due to its observed capacity to prevent $\mathrm{Hb}$-induced oxidation of LDL. ${ }^{120}$ Interestingly, from the proteomic analyses we found that $\mathrm{Hb}$ subunit- $\alpha$ and $\mathrm{Hb}$ subunit- $\beta$ were increased in abundance in the atheroma from men (Figure 16). Moreover, hemopexin was found at significantly increased abundance in the atheroma from women, alongside iron homeostasis group member - serotransferrin (Figure 16).

In addition, we also investigated the expression of ferritin and transferrin receptor 1 (TfR1) by IHC in sections of carotid atheroma from both men and women. Results from both of these stainings revealed that atheroma from men had significantly greater expression of both ferritin and TfR1, compared to women. Previously, our group had demonstrated a correlation with ferritin and TfR1 expression with the macrophage infiltration in carotid atheroma, ${ }^{121}$ hence herein, we further investigate the differences in macrophage
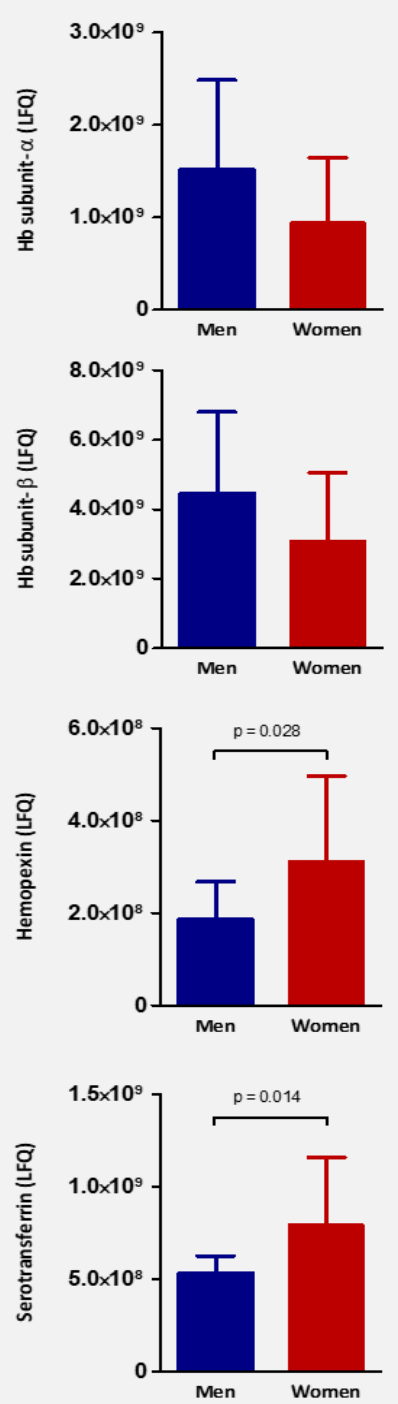

Figure 16 | Iron-related proteins with differential abundance between sexes.

Proteomic analyses of carotid atheroma ( $\mathrm{n}$ $=20$, equal sex distribution) revealed sex differences in the protein abundances of haemoglobin $(\mathrm{Hb})$, subunits $-\alpha$ and $-\beta$,

hemopexin and serotransferrin. LFQ label-free quantification. (Data mean $\pm \mathrm{SD}$ ) 

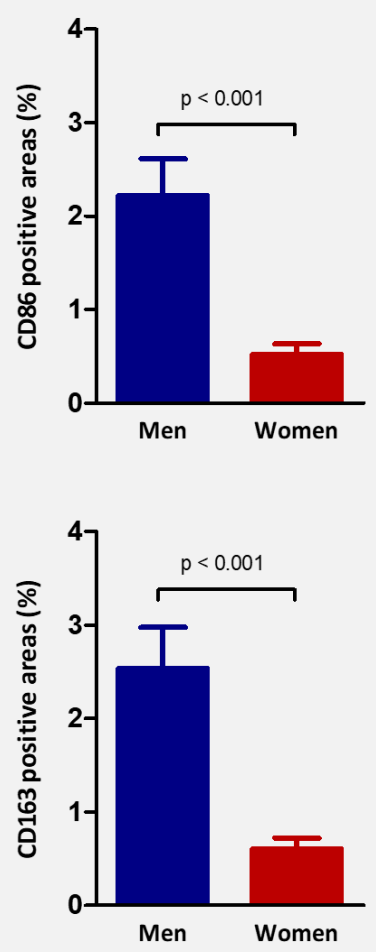

Figure 17 | Atheroma from men had significantly higher expression of both M1 and M2 macrophages.

Immunohistochemistry (IHC) analysis was performed in sections of carotid atheroma from both men $(n=19)$ and women $(n=40)$. IHC staining for CD86, a proinflammatory M1 macrophage marker, and CD163, an anti-inflammatory M2 macrophage marker. (Data mean $\pm \mathrm{SD}$ ).

infiltration and subtype between sexes. Macrophage markers were used for the IHC analyses, including pan-macrophage marker CD68; proinflammatory macrophage M1 subtype marker - CD86; and an anti-inflammatory macrophage M2 subtype marker-CD163. Results from macrophage IHC showed that atheroma from men possessed higher levels of overall macrophage infiltration, as well as both M1 macrophages and M2 macrophages (Figure 17). These results were consistent with previous findings that women have less macrophage infiltration, and potentially lower inflammatory reaction in atherosclerosis. ${ }^{122}$ Correlation analyses showed that macrophage expression colocalised with the ferritin and TfR 1 expression in atheroma from both men and women. Additionally, correlations were found between CD68 and activated macrophage subtype markers CD86 and CD163. The correlations may suggest that ferritin and TfR1, and by association labile iron, may be potential markers for macrophage activation in atherosclerosis.

In summary, this study showed that carotid atheroma from men, compared to women, had more advanced plaques, which were associated with significantly higher levels of macrophage infiltration and high iron stores in the circulation and plaques. These findings help contribute to the understanding of sex differences in atherosclerosis, specifically in plaque vulnerability. 


\section{Resistance training in postmenopausal women}

Physical inactivity is a major risk factor for the development of CVD and regular physical activity is a concept well-known to boost overall health in the population. As we had identified a number of potential markers related to atherosclerotic plaque development and plaque vulnerability, we aimed to investigate if physical activity could alter selected parameters that could be of potential benefit for reducing the development of CVD. For Papers IV-V, we had access to a physical exercise clinical trial called the "Strength study", based at the Division of Children's and Women's Health at Linköping University, which was centred around the effects of resistance training (RT) amongst postmenopausal women experiencing vasomotor symptoms. Obviously, with access to only postmenopausal women, this present a major caveat in our overall aim of this thesis to study sex differences in atherosclerosis and CVD. However, epidemiology has shown that after menopause there is a remarkable increase in stroke risk in women, which approximately doubles during the 10 years after menopause. ${ }^{1,123,124}$ Thus, these results may provide valuable insights into the effectiveness of RT as a potential intervention for CVD.

The clinical trial was a randomised controlled intervention trial, over a period of 15 weeks, and included 65 sedentary postmenopausal women who were randomly assigned into either a control group or RT intervention group. Clinical characteristics were recorded at baseline, and body anthropometrics and blood samples were obtained at two time-points in the trial at week-0 and week-15. At the conclusion of the study period, samples from 55 women were available for analysis - with seven women voluntarily removing themselves from the trial, and samples from three women were missing one or more timepoints. A flow chart detailing the clinical trial is presented in Figure 18.

As with all intervention trials, compliance must be taken into consideration. In the present study, the level of compliance to the RT-programme was set at an average of at least two RT sessions per week, excluded time off due to illness. At the completion of the intervention period, participants with good compliance were 15 out of 26 women (58\%). To account for compliance, the RT group was analysed in two forms; the first 
including all RT women (all-RT), and secondly just including those women with good compliance (compliant-RT).

A series of assays were performed on the isolated plasma samples obtained from week- 0 and week- 15 , including measurements of cytokines, chemokines, adipokines, myokines, iron status markers, lipids, hormones, and oxidative stress markers. A total of 51 analytes were investigated in plasma samples, however, not all analytes were detectable or presented within detectable ranges in enough participants for statistical consideration. A list of analytes that were measured within detectable ranges and were subjected to further statistical analysis are listed in Table 2 .

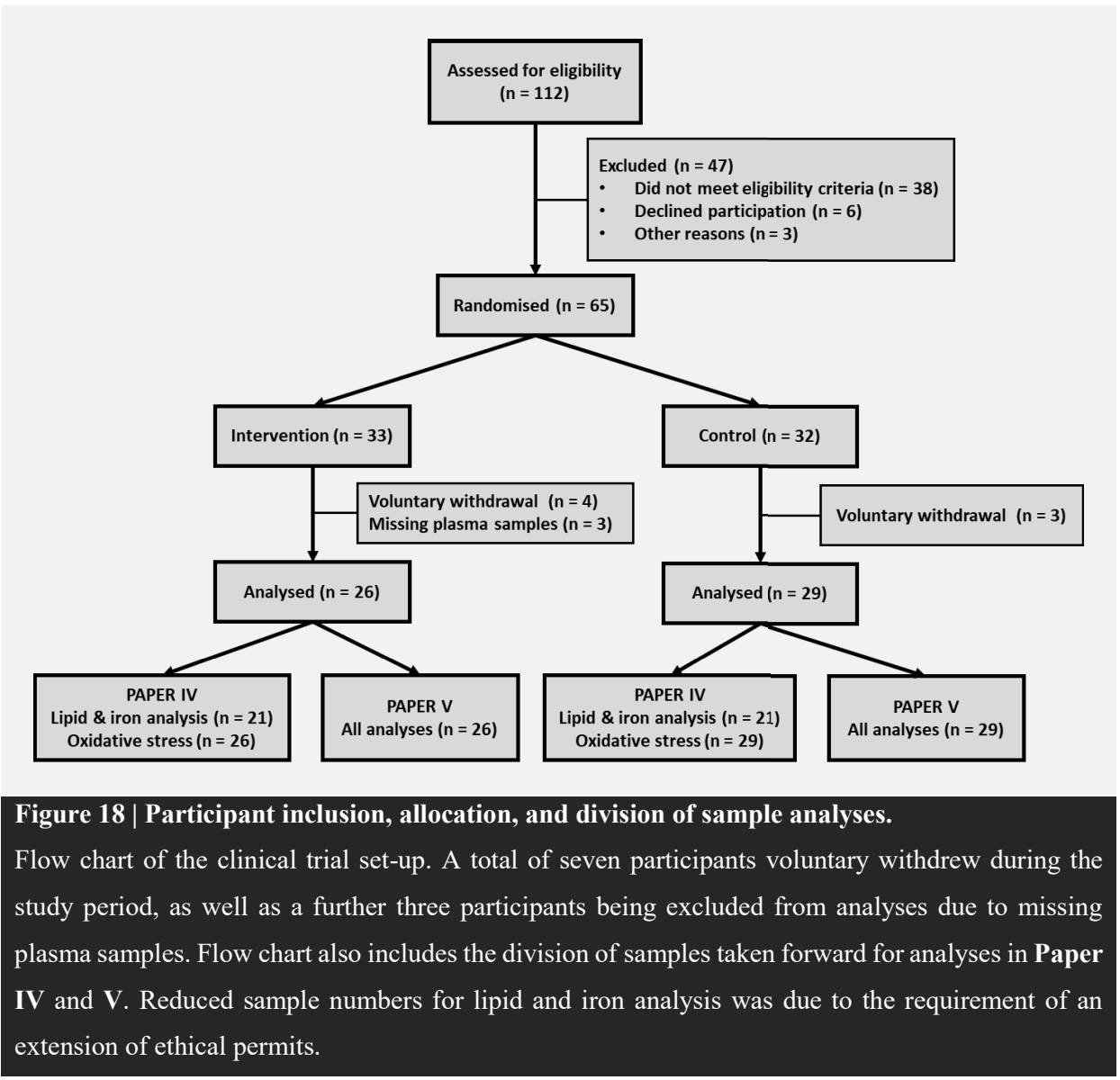


Table 2 | Detectable analytes measured in plasma from participants in the Strength Study.

Plasma analytes that were measured within detectable ranges of assays used, and that were carried forward for statistical analyses.

\begin{tabular}{ll}
\hline Group & Detected analytes \\
\hline Adipokines & $\begin{array}{l}\text { Adiponectin, adipsin, lipocalin-2, plasminogen activator inhibitor-1 (PAI- } \\
\text { 1), resistin. }\end{array}$ \\
Hormones & Leptin, sex hormone binding-globulin (SHBG), testosterone. \\
Iron status & Ferritin, iron, transferrin, transferrin saturation. \\
& Total cholesterol, LDL, HDL, triglycerides, non-HDL, apolipoprotein-A1, \\
Lipids & apolipoprotein-B. \\
Myokines & Brain-derived neurotrophic factor (BDNF), oncostatin-M, osteonectin. \\
Oxidative stress & Protein carbonyl, 4-hydroxynonenal, total antioxidant capacity. \\
Cytokines & MCP-1, tumour necrosis factor (TNF). \\
Other & CRP, MMP-2, MMP-9 \\
\hline
\end{tabular}

Once all measures were obtained, a series of statistical comparisons were performed, primarily comparing the two time-points in each control and RT groups, and between the study groups using a normalised value representing the change-over-time, calculated by divided the week- 15 value by the week- 0 value to obtain a percentage. RT exercise was associated with a number of significant alterations in plasma analytes, including those to be discussed herein; lipids and iron status (Paper IV), and adipokines and hormones (Paper V).

\section{RT associated effects on iron status and lipids (Paper IV)}

As introduced, lipid levels and iron status pose risks for the development on progression of CVD. Increased serum ferritin levels have been associated with the risk of CVD. ${ }^{125-128}$ Recent studies have reported associations between increased ferritin levels and increases in lipids, including total cholesterol, triglycerides, and LDL, in patients with CVD. ${ }^{129,130}$ Thus, in the Strength study, we aimed to analyse if RT could alter the plasma lipid profile and iron status in postmenopausal women. 

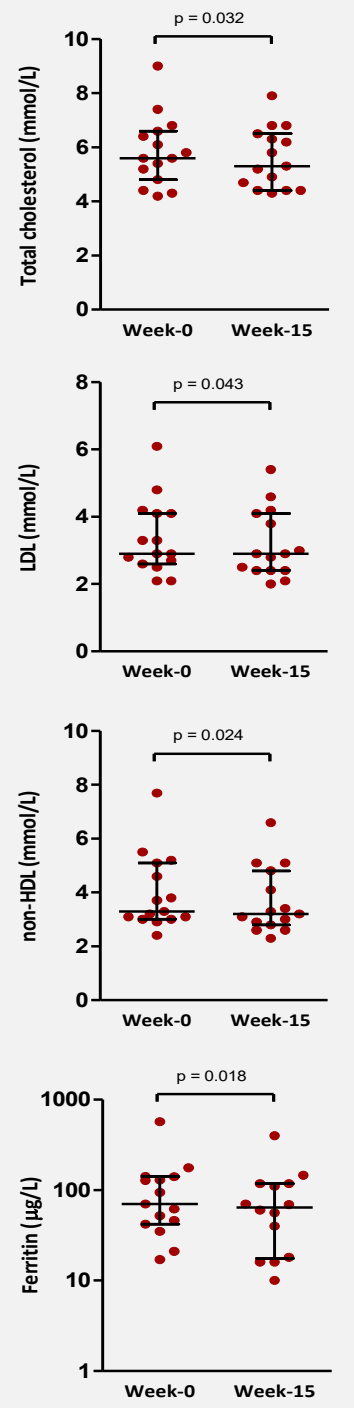

Figure 19 | Compliant-RT associated reductions in lipids and ferritin.

Women performing RT with good compliance $(\mathrm{n}=15)$ had associated significant reductions in plasma levels of total cholesterol, LDL, non-HDL, and ferritin when comparing week-15 and week-0 values. (Data is median $\pm \mathrm{IQR}$ ).
By comparing values from week- 0 and week-15 in the control, all-RT and compliant-RT groups, we found that participants performing RT with good compliance had significant reductions in plasma levels of total cholesterol, LDL, non-HDL, and ferritin (Figure 19). In contrast, no significant reductions were observed for participants in the control group, and in the all-RT group only a significant reduction in ferritin was retained $(p=0.01)$. When analysing the changeover-time values comparing the study groups, ferritin levels were reduced significantly more in both all-RT $(p=0.03)$ and compliant-RT $(p=0.01)$ groups when compared to the control group. Overall, these results showed an RT-associated reduction in selected plasma lipids and ferritin levels.

Exercise regimes, in postmenopausal women, have previously demonstrated associations with alterations in iron status and lipid profile. Aerobic exercise has produced decreases in body iron burden, including ferritin, iron, and transferrin saturation, ${ }^{131,132}$ and has shown to have beneficial outcomes in altering the lipid profile in postmenopausal women. ${ }^{132,133}$ RT trials have been utilised to a lesser extent overall, and specifically in postmenopausal women the majority of these trials have investigated the effect of RT in women who were overweight or obese. Results from these RT trials are somewhat contradictory in regard to the effect on lipid profile. A similar RT intervention study, over 12 weeks, in obese postmenopausal women also showed beneficial reductions in total cholesterol, LDL, and non-HDL. ${ }^{134}$ However, another RT intervention 
trial in obese/overweight postmenopausal women showed no alterations in lipid profile, ${ }^{135}$ and using a combined aerobic-RT regime showed no additional benefit of RT in altering the lipid profile. ${ }^{136}$

Correlation analyses were also performed based on the results of reduced ferritin and altered lipid profile. Correlations were performed for the data at week-0, week-15, and also a change-over-time value (week-15 minus week-0) for control and RT groups. The majority of correlations were observed when analysing the values representing change-over-time. A negative correlation between ferritin and HDL was found in all participants groups (Table 3). Additionally, positive correlations between ferritin and triglycerides, non-HDL, and apolipoprotein-B were found in the all-RT group when correlating the change-over-time (Table 3). In the context of the raw plasma measurements, this meant that in the all-RT group there were correlated reductions in ferritin, triglycerides, non-HDL, and apolipoprotein-B, and a contrasting increase in HDL levels. Overall, these changes in lipids can suggest an association of RT counteracting the atherogenic lipid profile with complementary reductions in ferritin. A large observational study investigating the age and sex relationships between serum ferritin and lipids levels, included a subgroup of 3539 women (mean age 39 years). ${ }^{130}$ Whilst this study covered a wide range of ages, 20-70 years, similar correlations were observed, including positive correlations between ferritin and total cholesterol and Table 3 | Correlation analyses of the change-over-time of plasma ferritin and lipid levels. Correlation analyses (Spearman) of the change-over-time values, week-15 minus week-0, for all participant groups in the Strength study; control, all-RT, and compliant-RT.

\begin{tabular}{|c|c|c|c|c|c|c|}
\hline \multirow{2}{*}{$\begin{array}{l}\text { Parameters } \\
\text { Ferritin }+\downarrow\end{array}$} & \multicolumn{2}{|c|}{ Control $(n=21)$} & \multicolumn{2}{|c|}{ All-RT $(n=21)$} & \multicolumn{2}{|c|}{ Compliant-RT $(\mathrm{n}=15)$} \\
\hline & Coefficient & p-value & Coefficient & p-value & Coefficient & p-value \\
\hline $\mathrm{TC}$ & -0.04 & 0.88 & 0.11 & 0.65 & -0.15 & 0.60 \\
\hline LDL & 0.08 & 0.72 & 0.36 & 0.13 & 0.17 & 0.55 \\
\hline HDL & -0.63 & $<0.01$ & -0.49 & 0.03 & -0.56 & 0.04 \\
\hline Triglycerides & -0.13 & 0.59 & 0.52 & 0.02 & 0.48 & 0.08 \\
\hline Non-HDL & 0.07 & 0.77 & 0.048 & 0.04 & 0.32 & 0.26 \\
\hline Apo-A1 & -0.31 & 0.17 & -0.15 & 0.54 & -0.38 & 0.19 \\
\hline Apo-B & -0.21 & 0.38 & 0.52 & 0.02 & 0.27 & 0.35 \\
\hline
\end{tabular}


triglycerides, as well as LDL, and a negative correlation between ferritin and HDL. ${ }^{130}$ This study also shows a clear increase in the serum ferritin levels in women with advancing age, albeit still significantly lower than men in all age groups. ${ }^{130}$ The molecular mechanisms linking increased iron burden and CVD, or metabolic syndrome, is unclear. However, one of the most probable is the relationship between iron and oxidative stress, with iron being a catalyst for ROS production in atherosclerosis. ${ }^{41,43}$ This relates back to the original 'iron hypothesis', by Sullivan, suggesting the sex differences in CVD are related to the iron load in the body. ${ }^{50}$ In the Strength study, we also analysed the plasma levels of oxidative stress markers, including protein carbonyl, lipid peroxidation, as well as total antioxidant capacity. However, no RT-associated effects were observed in plasma oxidative stress markers.

\section{RT associated effects on adipokines and hormones (Paper V)}

After menopause, a number of physiological alterations occur that can affect CVD risk, including but not limited to: reduced energy expenditure, redistribution of fat, increase in systemic inflammation, and a shift in sex hormone production. ${ }^{137-140}$ Thus, in the Strength study, we also wanted to analyse plasma levels of selected inflammation markers, hormones, adipokines and myokines. Whilst the majority of inflammation-related cytokines were undetectable in the assays used, we were able to measure a number of adipokines and hormones that displayed significant differences over the course of the trial. Results of plasma analyses of adipokines revealed significant differences in three adipokines, including adiponectin, lipocalin-2 and resistin. When comparing the levels of adipokines from the two-points, week- 0 and week-15, adiponectin levels were significantly altered in all three subgroups, control, all-RT and compliant-RT, lipocalin-2 was significantly reduced in both RT groups, and resistin was significantly reduced in the compliant-RT group (Figure 20).

Adipokines are cytokines secreted from adipose tissue and can be measured systemically and locally, by blood sampling or adipose tissue culturing, respectively. ${ }^{141}$, ${ }^{142}$ Adipokines can be proinflammatory or anti-inflammatory, with adiponectin being anti-inflammatory, and lipocalin-2 and resistin being proinflammatory. 
Adiponectin is produced by both white and brown adipose tissue and circulates in a variety of isoforms, which can exert differing biological effects. ${ }^{143},{ }^{144}$ In the Strength study, women participating in RT had associated decreases in plasma adiponectin levels. This observation seems to run contradictory to providing a potential benefit, as an increase in anti-inflammatory factors would be perceived as beneficial in the context of inflammation-driven diseases. Akin to the Strength study, another exercise intervention study, in obese postmenopausal women, observed significant decreases in adiponectin levels whilst still retaining an overall benefit. ${ }^{145}$ Currently, there is debate whether high levels of adiponectin are physiologically beneficial, as high levels of adiponectin in high-risk CVD populations have been associated with CVD mortality. ${ }^{146,147}$ Here, it must be reiterated that postmenopausal women are at an increased risk of CVD incidence, ${ }^{123}$ therefore high adiponectin levels may not be beneficial. Expanded analyses into the effect of exercise on particular adiponectin isoforms, such as high-molecular-weight adiponectin and adiponectin receptors, as these may discern the mechanisms responsible for altered adiponectin levels.
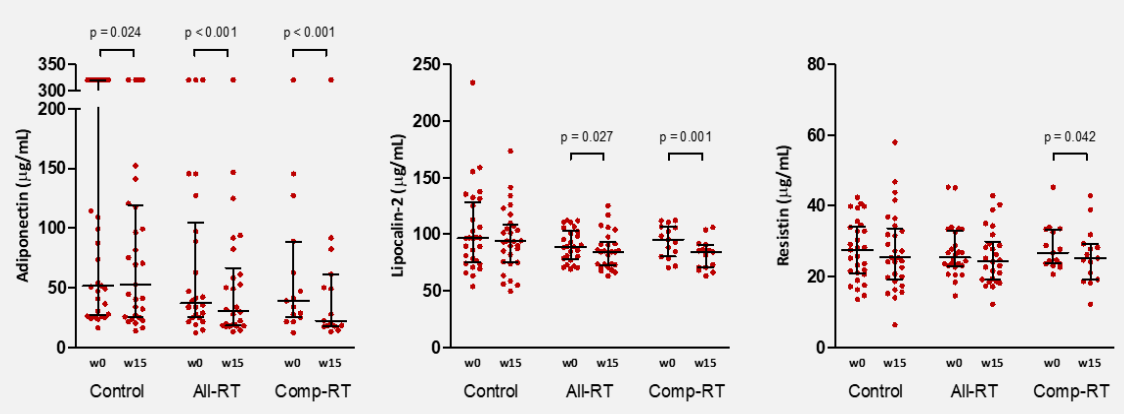

Figure 20 | RT was associated with significant reductions in plasma adipokine levels.

Postmenopausal women taking part in a 15 weeks RT programme had associated reductions in the

plasma levels of three adipokines, both adiponectin and resistin levels were significantly reduced in

the all-RT group $(\mathrm{n}=26)$ and compliant-RT $(\mathrm{n}=15)$ groups; levels of resistin were significantly reduced in the compliant-RT group. Additionally, a significant increase in adiponectin levels was observed in the control group $(\mathrm{n}=29)$. (Data is median $\pm \mathrm{IQR})$. 
Lipocalin-2 and resistin are both proinflammatory adipokines, and in the Strength study, significant decreases in plasma levels were observed in women who participated in RT (Figure 20). Lipocalin-2, also known as neutrophil gelatinaseassociated lipocalin (NGAL), is mainly produced by adipocytes in white adipose tissue. ${ }^{148}$ Lipocalin-2 has been associated with inflammatory and metabolic disorders, such as obesity, metabolic syndrome, and CVD. ${ }^{149-152}$ Resistin is mainly produced in peripheral blood macrophages, with a lesser proportion being secreted by adipocytes in white adipose tissue. ${ }^{153}$ Resistin has been found to directly interact with mechanisms related to atherosclerosis, via the promotion of lipid accumulation in macrophages, ${ }^{154}$ stimulating foam cells formation, and also by endothelial cells activation. ${ }^{155,} 156$ Lipocalin-2 and resistin have both been identified as independent predictors of cardiovascular events, which in addition to CRP level could provide better predictions for CVD. ${ }^{151,157}$ To our knowledge, the Strength study is the first to show reduced plasma levels of lipocalin-2 in association with RT in postmenopausal women. Whereas, similar results for decreases in plasma resistin levels have been seen in elderly obese postmenopausal women participating in a periodical RT regime. ${ }^{158,159}$

In addition to the described RT-associated alteration in adipokines, significant changes in testosterone and sex hormone-binding globulin (SHBG) were observed in the Strength study. Comparing the plasma levels at week-0 and week-15, a small significant increase in testosterone levels were observed in women in both the all-RT and compliant-RT groups. Moreover, when analysing the change-over-time values, both testosterone and SHBG levels were seen to increase significantly more in the allRT and compliant-RT groups, respectively (Figure 21). The observed increases in plasma testosterone levels run contradictory to most other exercise trials in postmenopausal women, which show trends to physical activity reducing testosterone levels. The differences may be the result of the type of exercise employed. It must be noted, that the absolute change in testosterone levels was small when comparing week0 and week-15, thus this small increase may lack clinical significance. 

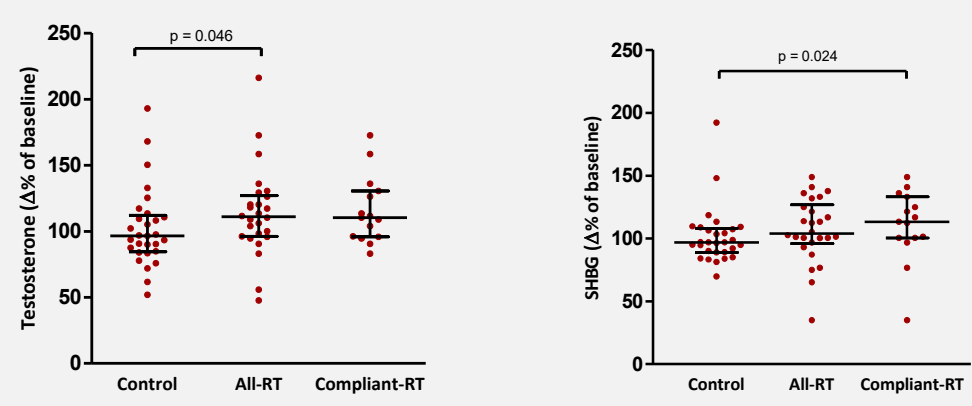

Figure 21 | RT over the course of 15-weeks was associated with significantly greater increases in plasma levels of testosterone and sex hormone binding globulin (SHBG)

Postmenopausal women randomised in control $(\mathrm{n}=29)$ or RT groups, presented as both all-RT $(\mathrm{n}=$ 26) and compliant-RT $(n=15)$. Plasma levels were measured at week- 0 and week- 0 . Statistical analysis was performed using 'change-over-time' values, week-15 normalised to baseline (\% of corresponding week-0 value). (Data is median $\pm \mathrm{IQR}$ ).

As previously mentioned, the Strength study only studied postmenopausal women, a limitation of the overall aim of this thesis. However, specific limitations must also be noted, the foremost being that the primary outcome of the Strength study was to investigate if RT could alleviate vasomotor symptoms, hot flushes, in postmenopausal women, and as such power calculations were based on this primary outcome variable. The aforementioned investigations relating to iron status, lipid profile, and inflammation are essentially secondary outcomes to this clinical trial, and as such the participant number that is relatively low for conclusive analysis of these analytes. Thus, additional studies with a larger participant group are required to confirm the results presented. In future studies, diet should also be accounted for, especially in the context of iron status and oxidative stress.

To summarise, the Strength study as a whole showed RT-associated alterations in a number of plasma analytes, including; ferritin, atherogenic lipids, and adipokines. The results taken together suggest that RT may be a beneficial intervention to potentially alleviate inflammation and atherogenesis in postmenopausal women, however, a larger study is needed with more women and the inclusion of diet must be taken into consideration. 


\section{Highlights (Papers I-V)}

As is evident, the works included in this thesis fall into two projects, with Papers I-III related to the proteomics and pathology of atherosclerosis, and Papers IV-V related to a clinical trial in postmenopausal women. Whilst from the onset these two projects seem independent, and arguably are, there are coherent concepts throughout.

To briefly highlight the major results from Papers I-V; we have found the following:

I. Proteomic analysis of distinct atheroma regions reduces the effect of plaque heterogeneity and identifies differences between sexes, such as apolipoprotein A-IV, cathepsin D, ferritin light chain and transthyretin.

II. Sexual dimorphism is present in the atheroma proteome, with particular focus on proteins related to blood coagulation and inflammatory response. Men having greater levels of lysozyme $\mathrm{C}$ and sPLA2-IIA, and women greater levels of serpins and afamin.

III. Atheroma iron stores and inflammatory macrophage infiltration differ between sexes and relate to plaque severity and vulnerability. Men developing more advanced and ruptured lesions associated with higher levels of inflammatory macrophages, and higher iron stores in the blood and plaques.

IV. RT intervention is associated with reduced ferritin and lipids, including total cholesterol, LDL and non-HDL, in postmenopausal women.

V. RT intervention is associated with reduced inflammatory adipokines, lipocalin-2 and resistin, in postmenopausal women.

Looking at these results, three concepts are highlighted - sex, iron, and inflammation. These are the major concepts that sew the illusive "red thread" throughout the projects. These concepts are all heavily involved with a hypothesis that aims to explain, in part, the development of CVD and atherosclerosis - the "iron hypothesis". Originally introduced in 1981, this hypothesis set out to explain sex differences observed in the heart disease risk and how levels of stored iron in the body may be associated with the distinct increase in body iron seen women after 48 
menopause. ${ }^{50}$ Over the next decades, this hypothesis has been further explored resulting in the better understanding of the role of iron in atherosclerosis, and the related oxidative stress and subsequent inflammation mechanisms. ${ }^{38-41,160,161}$ Whilst, I do not believe the "iron hypothesis" can explain atherosclerosis in its entirety; the results from Papers I$\mathbf{V}$ adds to the knowledge of sex differences, how iron and inflammation mediators may be involved, and how they can be potentially be modulated, in atherosclerosis. 


\section{CONCLUDING REMARKS}

Atherosclerosis-related CVD are the largest killers in the world, with distinctive differences in the incidence, mortality, and pathology between men and women. Exploring these sex differences is of key relevance in understanding the mechanisms driving atherosclerosis, and to help develop therapies for prevention and intervention. This thesis was aimed at investigating sex differences in atherosclerosis, with reference to the atheroma proteome and pathophysiology, and also the effects of exercise in postmenopausal women, a group whom are at high risk of CVD development.

Proteomic analyses of atheroma revealed distinctive differences between the atheroma from men and women, as well as distinctive differences between different regions of atherosclerotic lesions. Protein groups found to discriminate the atheroma proteome between men and women included proteins related to iron-metabolism, inflammatory response, blood coagulation, complement activation, and transport. Iron metabolism and inflammation were further explored from a pathophysiological perspective, where it was found that atheroma from men had higher levels of iron metabolism and inflammatory macrophages, which were associated with more advanced and ruptured plaque, when compared to atheroma from women. These sex differences in proteome and pathophysiology indicate that atheroma from men develop with a greater level of inflammation and more vulnerable phenotype, than atheroma from women that develop with less inflammation and more stable phenotype. These studies provide new insights into the atheroma proteome and vulnerability, which with further investigations could provide new candidate biomarkers for either, or both, men and women for therapeutic targeting.

The clinical trial aimed at investigating the effects of RT in postmenopausal women, was successful in identifying RT-associated decreases in ferritin, lipids, and inflammatory adipokines. These results suggest that the use of regular RT may be a beneficial intervention in reducing the levels of ferritin, lipids, and inflammation, all of which are risk factors for the development of CVD. However, validation studies are 
required in a larger cohort of postmenopausal women, in addition to the inclusion or complementary studies in middle-aged and older men.

In summary, the works including in this thesis further expand on the current knowledge of sex differences in atherosclerosis, with novel insights in the atheroma proteome, and also provides information on the potential of an exercise intervention in beneficially reducing the effect of known risk factors of CVD. 


\section{ACKNOWLEDGEMENTS}

Numerous people have contributed to the works presented in this thesis, and for that I would like to express my sincere gratitude for their support and help over years.

With special thanks to:

Wei Li, my main supervisor, for taking me on as a $\mathrm{PhD}$ student and continuing our work with atherosclerosis, and for also introducing me to the research at the Women's Clinic. Thank you for kindness and patience over the years, and for the constant encouragement.

Xi-Ming Yuan, my co-supervisor, for first taking me as a student back during my first year of my master's degree and welcoming me into your research group (and putting up with me for the past 7 years). Thank you for all the challenges and constructive criticism. I would not be the researcher I am today without it.

Helen Karlsson, my co-supervisor, and proteomics-guru. Your enthusiasm is contagious, and you always make me smile. Thank you for all your help in the lab... And for teaching me how to ski on that beginners' blue slope in Åre.

Marie Rubér, my co-supervisor, for introducing me to AIR and teaching me how to run Luminex, including all the troubleshooting, and all the help and contributions to the Strength Study projects.

Anna-Clara Spetz Holm, my co-supervisor, and Mats Hammar for allowing me to be part of the Strength Study, for showing me how clinical trials are run and organised. Thank you for the contributions to the Strength Study projects.

To all the co-authors of the papers included in this thesis, without whom this would not have been possible to complete.

Cynthia Veenstra, for your invaluable friendship, I am not sure if I should be thanking or blaming you for me having done a $\mathrm{PhD}$. Thank you for encouraging me to return to Sweden (see below). For always being there to help with everything and anything. For all the random trips, festivals, gigs, nights in and out.

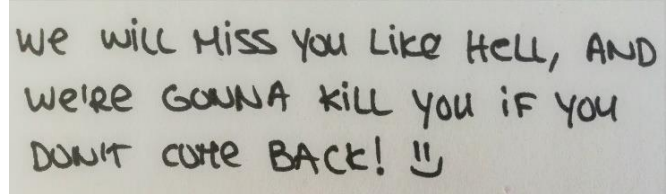

- Cynthia Veenstra \& Jelena Gacic, Linköping 2010 
Karin Wåhlén, for helping me retain my sanity inside and outside of the lab. We started at the lab around the same time, and we both got trapped there for years. For the afterworks, the ski-trips, the epic Fridays, and who could forget running $42.195 \mathrm{~km}$ dressed as KISS and drinking wine for the Medoc Marathon.

To my good friends in Linköping who've been there throughout the years: Antonio Lentini, Chris Sackmann, Linnéa Andersson, Magnus Ziegler, Riccardo Barchiesi, Robert 'Bobban' Lindau, Stefan Ljunggren, \& Valerie Sackmann. Thanks for all the good times, trips, parties, game nights... dragging me to the gym (Antonio/Bobban) ... and of course Ghostbusters!

All my friends at lab: Anders Carlsson, Bijar Ghafouri, Helen, Johanna Lönn, Karin, Maria Assenhöj, Niclas Stensson, \& Stefan. Thanks for making the lab a fun place to be, from the calibration nights, to the afterworks, and the ski trips!

To the other memorable friends over the years: Angelika 'Tall Lady' Holm, Anna Södergren, Daniel Appelgren, Emina Vorkapic, Johannes Stratmann, Malin Silverå-Ejneby, Maria Kopsida, Susanna Lönnqvist, and all the people I worked with in DOMFIL.

To my good friends from the UK and elsewhere: Kallie, one of my longest and best friends, we don't get to see each other very often but when we do it is like we haven't been away from one another! The old punchbowl lot: Kirsty, Sam, \& Welshy (I still don't believe your real name), we may have just started off working behind the bar together, but you've become the people I look forward to seeing whenever I drag myself back to Crawley, and thanks for coining my nickname Hammy. Arnoud, for all the laughs and good time over the years at Lowlands festival and elsewhere! Ivana, my crazy Czech tall lady, the laugh, the dancing, the happiness, thanks for it all!

To my family, Mum, Dad, Michelle, and everyone else: I know you miss not having me live closer to home, but I can't thank you enough for always being there whenever and wherever. No matter how many miles divides us, you'll always be "home" to me.

To Adam, my much better half. Thank you for your artistic flair with designing my cover... but most of all, thank you for being in my life and making me a better person!

And finally, thanks to Me! I don't know why people don't give credit to themselves in their thesis... screw egotism, I worked damn hard for this! 


\section{REFERENCES}

1. Global health estimates 2016: Deaths by cause, age, sex, by country and by region, 2000-2016. 2018

2. de Mestral C, Stringhini SJCCR. Socioeconomic status and cardiovascular disease: An update. 2017;19:115

3. Mendis S. The contribution of the framingham heart study to the prevention of cardiovascular disease: A global perspective. Progress in Cardiovascular Diseases. 2010;53:10-14

4. Yusuf S, Hawken S, Ounpuu S, Dans T, Avezum A, Lanas F, et al. Effect of potentially modifiable risk factors associated with myocardial infarction in 52 countries (the interheart study): Case-control study. The Lancet. 2004;364:937-952

5. Schwartz CJ, Mitchell JR. The morphology, terminology and pathogenesis of arterial plaques. Postgraduate medical journal. 1962;38:25-34

6. Ross R. Atherosclerosis — an inflammatory disease. 1999;340:115-126

7. Libby P, Ridker PM, Hansson GK. Inflammation in atherosclerosis: From pathophysiology to practice. Journal of the American College of Cardiology. 2009;54:2129-2138

8. Ross R, Glomset J, Harker L. Response to injury and atherogenesis. The American journal of pathology. 1977;86:675-684

9. Sprague AH, Khalil RA. Inflammatory cytokines in vascular dysfunction and vascular disease. Biochemical pharmacology. 2009;78:539-552

10. Cybulsky MI, Iiyama K, Li H, Zhu S, Chen M, Iiyama M, et al. A major role for vcam-1, but not icam1 , in early atherosclerosis. The Journal of clinical investigation. 2001;107:1255-1262

11. Gu L, Okada Y, Clinton SK, Gerard C, Sukhova GK, Libby P, et al. Absence of monocyte chemoattractant protein-1 reduces atherosclerosis in low density lipoprotein receptor-deficient mice. Molecular Cell. 1998;2:275-281

12. Mach F, Sauty A, Iarossi AS, Sukhova GK, Neote K, Libby P, et al. Differential expression of three t lymphocyte-activating cxc chemokines by human atheroma-associated cells. The Journal of Clinical Investigation. 1999;104:1041-1050

13. Libby P, Geng YJ, Aikawa M, Schoenbeck U, Mach F, Clinton SK, et al. Macrophages and atherosclerotic plaque stability. Current Opinion in Lipidology. 1996;7:330-335

14. Yuan XM. Apoptotic macrophage-derived foam cells of human atheromas are rich in iron and ferritin, suggesting iron-catalysed reactions to be involved in apoptosis. Free Radical Research. 1999;30:221231

15. Li W, Dalen H, Eaton JW, Yuan X-M. Apoptotic death of inflammatory cells in human atheroma. Arteriosclerosis, Thrombosis, and Vascular Biology. 2001;21:1124-1130

16. Kzhyshkowska J, Neyen C, Gordon S. Role of macrophage scavenger receptors in atherosclerosis. Immunobiology. 2012;217:492-502

17. Geng Y, Kodama T, Hansson GK. Differential expression of scavenger receptor isoforms during monocyte-macrophage differentiation and foam cell formation. 1994;14:798-806

18. Chistiakov DA, Bobryshev YV, Nikiforov NG, Elizova NV, Sobenin IA, Orekhov AN. Macrophage phenotypic plasticity in atherosclerosis: The associated features and the peculiarities of the expression of inflammatory genes. International Journal of Cardiology. 2015;184:436-445

19. Lao $\mathrm{KH}$, Zeng L, Xu Q. Endothelial and smooth muscle cell transformation in atherosclerosis. 2015;26:449-456

20. Kavurma MM, Rayner KJ, Karunakaran D. The walking dead: Macrophage inflammation and death in atherosclerosis. 2017;28:91-98

21. Björkerud S, Björkerud B. Apoptosis is abundant in human atherosclerotic lesions, especially in inflammatory cells (macrophages and t cells), and may contribute to the accumulation of gruel and plaque instability. The American journal of pathology. 1996;149:367-380

22. Li W, Hellsten A, Nyhalah JD, Yuan X-M. Enhanced expression of natural resistance-associated macrophage protein 1 in atherosclerotic lesions may be associated with oxidized lipid-induced apoptosis. Annals of the New York Academy of Sciences. 2004;1030:202-207

23. Galis ZS, Sukhova GK, Kranzhöfer R, Clark S, Libby P. Macrophage foam cells from experimental atheroma constitutively produce matrix-degrading proteinases. 1995;92:402-406

24. Li W, Kornmark L, Jonasson L, Forssell C, Yuan X-M. Cathepsin 1 is significantly associated with apoptosis and plaque destabilization in human atherosclerosis. Atherosclerosis. 2009;202:92-102

25. Sjöberg S, Shi G-P. Cysteine protease cathepsins in atherosclerosis and abdominal aortic aneurysm. Clinical reviews in bone and mineral metabolism. 2011;9:138-147

26. Kolodgie FD, Burke AP, Nakazawa G, Virmani R. Is pathologic intimal thickening the key to understanding early plaque progression in human atherosclerotic disease? 2007;27:986-989 
27. Ferns GAA, Heikal L. Hypoxia in atherogenesis. 2017;68:472-493

28. Moreno PR, Purushothaman KR, Zias E, Sanz J, Fuster V. Neovascularization in human atherosclerosis. Current Molecular Medicine. 2006;6:457-477

29. Stary HC, Chandler AB, Dinsmore RE, Fuster V, Glagov S, Insull W, et al. A definition of advanced types of atherosclerotic lesions and a histological classification of atherosclerosis. 1995;92:1355-1374

30. Hansson GK, Libby P, Tabas I. Inflammation and plaque vulnerability. Journal of Internal Medicine. 2015;278:483-493

31. Sluijter JPG, Pulskens WPC, Schoneveld AH, Velema E, Strijder CF, Moll F, et al. Matrix metalloproteinase 2 is associated with stable and matrix metalloproteinases 8 and 9 with vulnerable carotid atherosclerotic lesions. Stroke. 2006;37:235-239

32. Razuvaev A, Ekstrand J, Folkersen L, Agardh H, Markus D, Swedenborg J, et al. Correlations between clinical variables and gene-expression profiles in carotid plaque instability. European Journal of Vascular and Endovascular Surgery. 2011;42:722-730

33. Jefferis BJ, Whincup P, Welsh P, Wannamethee G, Rumley A, Lennon L, et al. Prospective study of matrix metalloproteinase-9 and risk of myocardial infarction and stroke in older men and women. Atherosclerosis. 2010;208:557-563

34. Blankenberg S, Rupprecht HJ, Poirier O, Bickel C, Smieja M, Hafner G, et al. Plasma concentrations and genetic variation of matrix metalloproteinase 9 and prognosis of patients with cardiovascular disease. Circulation. 2003;107:1579-1585

35. Kormi I, Nieminen MT, Havulinna AS, Zeller T, Blankenberg S, Tervahartiala T, et al. Matrix metalloproteinase- 8 and tissue inhibitor of matrix metalloproteinase-1 predict incident cardiovascular disease events and all-cause mortality in a population-based cohort. European Journal of Preventive Cardiology. 2017;24:1136-1144

36. Tuomainen AM, Nyyssönen K, Laukkanen JA, Tervahartiala T, Tuomainen T-P, Salonen JT, et al. Serum matrix metalloproteinase-8 concentrations are associated with cardiovascular outcome in men. Arteriosclerosis, Thrombosis, and Vascular Biology. 2007;27:2722-2728

37. de Valk B, Marx JJM. Iron, atherosclerosis, and ischemic heart disease. Archives of Internal Medicine. 1999; $159: 1542-1548$

38. Howes PS, Zacharski LR, Sullivan J, Chow B. Role of stored iron in atherosclerosis. Journal of Vascular Nursing. 2000;18:109-116

39. Meyers DG. The iron hypothesis:Does iron play a role in atherosclerosis? Transfusion. 2000;40:10231029

40. Sullivan JL. Iron in arterial plaque: A modifiable risk factor for atherosclerosis. Biochimica et Biophysica Acta (BBA) - General Subjects. 2009;1790:718-723

41. Yuan X-M, Li W. Iron involvement in multiple signaling pathways of atherosclerosis: A revisited hypothesis. Current Medicinal Chemistry. 2008;15:2157-2172

42. Corti M-C, Gaziano M, Hennekens CH. Iron status and risk of cardiovascular disease. Annals of Epidemiology. 1997; 7:62-68

43. Darley-Usmar V, Halliwell BJPR. Blood radicals: Reactive nitrogen species, reactive oxygen species, transition metal ions, and the vascular system. Pharmaceutical Research. 1996;13:649-662

44. Vinchi F, Muckenthaler MU, Da Silva MC, Balla G, Balla J, Jeney V. Atherogenesis and iron: From epidemiology to cellular level. Frontiers in Pharmacology. 2014;5

45. Kattoor AJ, Pothineni NVK, Palagiri D, Mehta JLJCAR. Oxidative stress in atherosclerosis. Current Atherosclerosis Reports. 2017;19:42

46. Badimon L, Vilahur G. Thrombosis formation on atherosclerotic lesions and plaque rupture. Journal of Internal Medicine. 2014;276:618-632

47. Viles-Gonzalez JF, Badimon JJ, Fuster V. Atherothrombosis: A widespread disease with unpredictable and life-threatening consequences. European Heart Journal. 2004;25:1197-1207

48. Heemskerk JWM, Bevers EM, Lindhout T. Platelet activation and blood coagulation. Thromb Haemost. 2002;88:186-193

49. Smith SA, Travers RJ, Morrissey JH. How it all starts: Initiation of the clotting cascade. Critical reviews in biochemistry and molecular biology. 2015;50:326-336

50. Sullivan J. Iron and the sex differences in heart disease risk. The Lancet. 1981;317:1293-1294

51. Lansky AJ, Ng VG, Maehara A, Weisz G, Lerman A, Mintz GS, et al. Gender and the extent of coronary atherosclerosis, plaque composition, and clinical outcomes in acute coronary syndromes. JACC: Cardiovascular Imaging. 2012;5:S62-S72

52. Singh N, Moody AR, Zhang B, Kaminski I, Kapur K, Chiu S, et al. Age-specific sex differences in magnetic resonance imaging-depicted carotid intraplaque hemorrhage. Stroke. 2017;48:2129-2135

53. Blackstock WP, Weir MP. Proteomics: Quantitative and physical mapping of cellular proteins. Trends in Biotechnology. 1999;17:121-127 
54. Abbott A. And now for the proteome. Nature. 2001;409:747

55. Durán MC, Martín-Ventura JL, Mohammed S, Barderas MG, Blanco-Colio LM, Mas S, et al. Atorvastatin modulates the profile of proteins released by human atherosclerotic plaques. European Journal of Pharmacology. 2007;562:119-129

56. Vivanco F, Martín-Ventura JL, Duran MC, Barderas MG, Blanco-Colio L, Dardé VM, et al. Quest for novel cardiovascular biomarkers by proteomic analysis. Journal of Proteome Research. 2005;4:11811191

57. Lepedda AJ, Cigliano A, Cherchi GM, Spirito R, Maggioni M, Carta F, et al. A proteomic approach to differentiate histologically classified stable and unstable plaques from human carotid arteries. Atherosclerosis. 2009;203:112-118

58. Bagnato C, Thumar J, Mayya V, Hwang S-I, Zebroski H, Claffey KP, et al. Proteomics analysis of human coronary atherosclerotic plaque. A Feasibility Study of Direct Tissue Proteomics by Liquid Chromatography and Tandem Mass Spectrometry. 2007;6:1088-1102

59. Viiri LE, Full LE, Navin TJ, Begum S, Didangelos A, Astola N, et al. Smooth muscle cells in human atherosclerosis: Proteomic profiling reveals differences in expression of annexin a1 and mitochondrial proteins in carotid disease. Journal of Molecular and Cellular Cardiology. 2013;54:65-72

60. Porcelli B, Ciari I, Felici C, Pagani R, Banfi C, Brioschi M, et al. Proteomic analysis of atherosclerotic plaque. Biomedicine \& Pharmacotherapy. 2010;64:369-372

61. Lind L, Ärnlöv J, Lindahl B, Siegbahn A, Sundström J, Ingelsson E. Use of a proximity extension assay proteomics chip to discover new biomarkers for human atherosclerosis. Atherosclerosis. 2015;242:205210

62. Eberini I, Wait R, Calabresi L, Sensi C, Miller I, Gianazza E. A proteomic portrait of atherosclerosis. Journal of Proteomics. 2013;82:92-112

63. Malaud E, Piquer D, Merle D, Molina L, Guerrier L, Boschetti E, et al. Carotid atherosclerotic plaques: Proteomics study after a low-abundance protein enrichment step. Electrophoresis. 2012;33:470-482

64. Langley SR, Willeit K, Didangelos A, Matic LP, Skroblin P, Barallobre-Barreiro J, et al. Extracellular matrix proteomics identifies molecular signature of symptomatic carotid plaques. The Journal of Clinical Investigation. 2017;127:1546-1560

65. Kleijn DPVd, Moll FL, Hellings WE, Ozsarlak-Sozer G, Bruin Pd, Doevendans PA, et al. Local atherosclerotic plaques are a source of prognostic biomarkers for adverse cardiovascular events. Arteriosclerosis, Thrombosis, and Vascular Biology. 2010;30:612-619

66. Duran MC, Mas S, Martin-Ventura JL, Meilhac O, Michel JB, Gallego-Delgado J, et al. Proteomic analysis of human vessels: Application to atherosclerotic plaques. Proteomics. 2003;3:973-978

67. Martin-Ventura JL, Duran MC, Blanco-Colio LM, Meilhac O, Leclercq A, Michel J-B, et al. Identification by a differential proteomic approach of heat shock protein 27 as a potential marker of atherosclerosis. Circulation. 2004;110:2216-2219

68. Rocchiccioli S, Pelosi G, Rosini S, Marconi M, Viglione F, Citti L, et al. Secreted proteins from carotid endarterectomy: An untargeted approach to disclose molecular clues of plaque progression. Journal of Translational Medicine. 2013;11:260

69. Baetta R, Pontremoli M, Martinez Fernandez A, Spickett CM, Banfi C. Proteomics in cardiovascular diseases: Unveiling sex and gender differences in the era of precision medicine. Journal of Proteomics. 2018;173:62-76

70. Pedersen BK. The diseasome of physical inactivity - and the role of myokines in muscle-fat cross talk. The Journal of Physiology. 2009;587:5559-5568

71. Safdar A, Hamadeh MJ, Kaczor JJ, Raha S, deBeer J, Tarnopolsky MA. Aberrant mitochondrial homeostasis in the skeletal muscle of sedentary older adults. PLOS ONE. 2010;5:e10778

72. WHO. Global health observatory data repository: Prevalence of insufficient physical activity among adults. World Health Organization. 2017

73. Lavie CJ, Thomas RJ, Squires RW, Allison TG, Milani RV. Exercise training and cardiac rehabilitation in primary and secondary prevention of coronary heart disease. Mayo Clinic Proceedings. 2009;84:373383

74. Fletcher GF, Balady G, Blair SN, Blumenthal J, Caspersen C, Chaitman B, et al. Statement on exercise: Benefits and recommendations for physical activity programs for all americans. Circulation. 1996;94:857-862

75. Palmefors H, DuttaRoy S, Rundqvist B, Börjesson M. The effect of physical activity or exercise on key biomarkers in atherosclerosis - a systematic review. Atherosclerosis. 2014;235:150-161

76. Mury P, Chirico EN, Mura M, Millon A, Canet-Soulas E, Pialoux V. Oxidative stress and inflammation, key targets of atherosclerotic plaque progression and vulnerability: Potential impact of physical activity. Sports Medicine. 2018;48:2725-2741 
77. Pinto PR, Rocco DDFM, Okuda LS, Machado-Lima A, Castilho G, da Silva KS, et al. Aerobic exercise training enhances the in vivo cholesterol trafficking from macrophages to the liver independently of changes in the expression of genes involved in lipid flux in macrophages and aorta. Lipids in Health and Disease. 2015;14:109

78. Petersen AMW, Pedersen BK. The anti-inflammatory effect of exercise. Journal of Applied Physiology. 2005;98:1154-1162

79. Thompson PD, Buchner D, Piña IL, Balady GJ, Williams MA, Marcus BH, et al. Exercise and physical activity in the prevention and treatment of atherosclerotic cardiovascular disease. Circulation. 2003;107:3109-3116

80. Bernecker C, Scherr J, Schinner S, Braun S, Scherbaum WA, Halle M. Evidence for an exercise induced increase of tnf- $\alpha$ and il-6 in marathon runners. Scandinavian Journal of Medicine \& Science in Sports. 2013;23:207-214

81. Berin E, Hammar ML, Lindblom H, Lindh-Åstrand L, Spetz Holm A-CE. Resistance training for hot flushes in postmenopausal women: Randomized controlled trial protocol. Maturitas. 2016;85:96-103

82. Chomczynski P, Sacchi N. Single-step method of rna isolation by acid guanidinium thiocyanate-phenolchloroform extraction. Analytical Biochemistry. 1987;162:156-159

83. Görg A, Weiss W, Dunn MJ. Current two-dimensional electrophoresis technology for proteomics. 2004;4:3665-3685

84. Görg A, Drews O, Lück C, Weiland F, Weiss W. 2-de with ipgs. 2009;30:S122-S132

85. Shevchenko A, Wilm M, Vorm O, Mann M. Mass spectrometric sequencing of proteins from silverstained polyacrylamide gels. Analytical Chemistry. 1996;68:850-858

86. Lopez MF, Berggren K, Chernokalskaya E, Lazarev A, Robinson M, Patton WF. A comparison of silver stain and sypro ruby protein gel stain with respect to protein detection in two-dimensional gels and identification by peptide mass profiling. 2000;21:3673-3683

87. Nishihara JC, Champion KM. Quantitative evaluation of proteins in one- and two-dimensional polyacrylamide gels using a fluorescent stain. 2002;23:2203-2215

88. Tanaka K, Waki H, Ido Y, Akita S, Yoshida Y, Yoshida T, et al. Protein and polymer analyses up to $\mathrm{m} / \mathrm{z}$ 100000 by laser ionization time-of-flight mass spectrometry. 1988;2:151-153

89. Ghafouri B, Karlsson H, Mörtstedt H, Lewander A, Tagesson C, Lindahl M. 2,5-dihydroxybenzoic acid instead of $\alpha$-cyano-4-hydroxycinnamic acid as matrix in matrix-assisted laser desorption/ionization timeof-flight mass spectrometry for analyses of in-gel digests of silver-stained proteins. Analytical Biochemistry. 2007;371:121-123

90. Hortin GL. The maldi-tof mass spectrometric view of the plasma proteome and peptidome. Clinical Chemistry. 2006;52:1223

91. Levin Y, Schwarz E, Wang L, Leweke FM, Bahn S. Label-free lc-ms/ms quantitative proteomics for large-scale biomarker discovery in complex samples. 2007;30:2198-2203

92. Sandin M, Chawade A, Levander F. Is label-free lc-ms/ms ready for biomarker discovery? 2015;9:289_ 294

93. Paizs B, Suhai S. Fragmentation pathways of protonated peptides. 2005;24:508-548

94. Jansen JJ, Szymańska E, Hoefsloot HCJ, Jacobs DM, Strassburg K, Smilde AK. Between metabolite relationships: An essential aspect of metabolic change. Metabolomics : Official journal of the Metabolomic Society. 2012;8:422-432

95. Wheelock ÅM, Wheelock CE. Trials and tribulations of 'omics data analysis: Assessing quality of simcabased multivariate models using examples from pulmonary medicine. Molecular BioSystems. 2013;9:2589-2596

96. Nordén B, Broberg P, Lindberg C, Plymoth A. Analysis and understanding of high-dimensionality data by means of multivariate data analysis. Chemistry \& Biodiversity. 2005;2:1487-1494

97. Ramos-Vara JA. Technical aspects of immunohistochemistry. Veterinary Pathology. 2005;42:405-426

98. Mahmood T, Yang P-C. Western blot: Technique, theory, and trouble shooting. North American journal of medical sciences. 2012;4:429-434

99. Madamanchi NR, Runge MS. Western blotting. In: Wang DH, ed. Angiotensin protocols. Totowa, NJ: Humana Press; 2001:245-256.

100. Vashist SK, Luong JHT. Chapter 5 - enzyme-linked immunoassays. In: Vashist SK, Luong JHT, eds. Handbook of immunoassay technologies. Academic Press; 2018:97-127.

101. Olson FJ, Sihlbom C, Davidsson P, Hulthe J, Fagerberg B, Bergström G. Consistent differences in protein distribution along the longitudinal axis in symptomatic carotid atherosclerotic plaques. Biochemical and Biophysical Research Communications. 2010;401:574-580

102. de la Cuesta F, Alvarez-Llamas G, Maroto AS, Donado A, Zubiri I, Posada M, et al. A proteomic focus on the alterations occurring at the human atherosclerotic coronary intima. Molecular \& Cellular Proteomics. 2011;10:M110.003517 
103. Chen S, Birk DE. The regulatory roles of small leucine-rich proteoglycans in extracellular matrix assembly. The FEBS Journal. 2013;280:2120-2137

104. Halper J, Kjaer M. Basic components of connective tissues and extracellular matrix: Elastin, fibrillin, fibulins, fibrinogen, fibronectin, laminin, tenascins and thrombospondins. In: Halper J, ed. Progress in heritable soft connective tissue diseases. Dordrecht: Springer Netherlands; 2014:31-47.

105. Lehman W, Morgan KG. Structure and dynamics of the actin-based smooth muscle contractile and cytoskeletal apparatus. Journal of muscle research and cell motility. 2012;33:461-469

106. García-Arguinzonis M, Padró T, Lugano R, Llorente-Cortes V, Badimon L. Low-density lipoproteins induce heat shock protein 27 dephosphorylation, oligomerization, and subcellular relocalization in human vascular smooth muscle cells. Arteriosclerosis, Thrombosis, and Vascular Biology. 2010;30:1212-1219

107. Shu Y-N, Zhang F, Bi W, Dong L-H, Zhang D-D, Chen R, et al. Sm22 $\alpha$ inhibits vascular inflammation via stabilization of ikb $\alpha$ in vascular smooth muscle cells. Journal of Molecular and Cellular Cardiology. 2015;84:191-199

108. Assinder SJ, Stanton J-AL, Prasad PD. Transgelin: An actin-binding protein and tumour suppressor. The International Journal of Biochemistry \& Cell Biology. 2009;41:482-486

109. Vorlova S, Koch M, Manthey HD, Cochain C, Busch M, Chaudhari SM, et al. Coagulation factor xii induces pro-inflammatory cytokine responses in macrophages and promotes atherosclerosis in mice. Thromb Haemost. 2017;26:176-187

110. Pike RN, Buckle AM, le Bonniec BF, Church FC. Control of the coagulation system by serpins. The FEBS Journal. 2005;272:4842-4851

111. Conlan MG, Folsom AR, Finch A, Davis CE, Marcucci G, Sorlie P, et al. Antithrombin iii: Associations with age, race, sex and cardiovascular disease risk factors. Thromb Haemost. 1994;71:551-556

112. Jerkovic L, Voegele AF, Chwatal S, Kronenberg F, Radcliffe CM, Wormald MR, et al. Afamin is a novel human vitamin e-binding glycoprotein characterization and in vitro expression. Journal of Proteome Research. 2005;4:889-899

113. Dieplinger H, Dieplinger B. Afamin - a pleiotropic glycoprotein involved in various disease states. Clinica Chimica Acta. 2015;446:105-110

114. Mallat Z, Lambeau G, Tedgui A. Lipoprotein-associated and secreted phospholipases a2 in cardiovascular disease. Circulation. 2010;122:2183-2200

115. Lew J, Sanghavi M, Ayers CR, McGuire DK, Omland T, Atzler D, et al. Sex-based differences in cardiometabolic biomarkers. Circulation. 2017;135:544-555

116. Abdul-Salam VB, Ramrakha P, Krishnan U, Owen DR, Shalhoub J, Davies AH, et al. Identification and assessment of plasma lysozyme as a putative biomarker of atherosclerosis. Arteriosclerosis, Thrombosis, and Vascular Biology. 2010;30:1027-1033

117. Pettersson C, Karlsson H, Ståhlman M, Larsson T, Fagerberg B, Lindahl M, et al. Ldl-associated apolipoprotein $\mathrm{j}$ and lysozyme are associated with atherogenic properties of ldl found in type 2 diabetes and the metabolic syndrome. Journal of Internal Medicine. 2011;269:306-321

118. Holme I, Aastveit AH, Hammar N, Jungner I, Walldius G. High blood hemoglobin concentration as risk factor of major atherosclerotic cardiovascular events in 114,159 healthy men and women in the apolipoprotein mortality risk study (amoris). Annals of Medicine. 2012;44:476-486

119. Watanabe J, Chou KJ, Liao JC, Miao Y, Meng H-H, Ge H, et al. Differential association of hemoglobin with proinflammatory high density lipoproteins in atherogenic/hyperlipidemic mice: A novel biomarker of atherosclerosis. The Journal of Biological Chemistry. 2007;282:23698-23707

120. Miller YI, Smith A, Morgan WT, Shaklai N. Role of hemopexin in protection of low-density lipoprotein against hemoglobin-induced oxidation. Biochemistry. 1996;35:13112-13117

121. Li W, Xu L-H, Forssell C, Sullivan JL, Yuan X-M. Overexpression of transferrin receptor and ferritin related to clinical symptoms and destabilization of human carotid plaques. Experimental Biology and Medicine. 2008;233:818-826

122. Hellings WE, Pasterkamp G, Verhoeven BAN, De Kleijn DPV, De Vries J-PPM, Seldenrijk KA, et al. Gender-associated differences in plaque phenotype of patients undergoing carotid endarterectomy. Journal of Vascular Surgery. 2007;45:289-296

123. Lisabeth L, Bushnell C. Stroke risk in women: The role of menopause and hormone therapy. The Lancet Neurology. 2012;11:82-91

124. Ota H, Reeves MJ, Zhu DC, Majid A, Collar A, Yuan C, et al. Sex differences of high-risk carotid atherosclerotic plaque with less than $50 \%$ stenosis in asymptomatic patients: An in vivo $3 \mathrm{t}$ mri study. American Journal of Neuroradiology. 2013;34:1049

125. Salonen JT, Nyyssönen K, Korpela H, Tuomilehto J, Seppänen R, Salonen R. High stored iron levels are associated with excess risk of myocardial infarction in eastern finnish men. Circulation. 1992;86:803811 
126. Haidari M, Javadi E, Sanati A, Hajilooi M, Ghanbili J. Association of increased ferritin with premature coronary stenosis in men. Clinical Chemistry. 2001;47:1666

127. Ahluwalia N, Genoux A, Ferrieres J, Perret B, Carayol M, Drouet L, et al. Iron status is associated with carotid atherosclerotic plaques in middle-aged adults. The Journal of Nutrition. 2010;140:812-816

128. Ma H, Lin H, Hu Y, Li X, He W, Jin X, et al. Serum ferritin levels are associated with carotid atherosclerosis in chinese postmenopausal women: The shanghai changfeng study. British Journal of Nutrition. 2015;114:1064-1071

129. Shipra, Gupta BK, Solanki R, Punia H, Agarwal V, Kaur J, et al. Relationship of lipid profile and serum ferritin levels with acute myocardial infarction. Journal of Clinical \& Diagnostic Research. 2014;8:1013

130. Ellidag HY, Eren E, Akdag M, Giray O, Kiraz K, Yilmaz N. The relationship between serum ferritin levels and serum lipids and hdl function with respect to age and gender. The Ukrainian Biochemical Journal. 2016;88:76-86

131. Bartfay W, Bartfay E. A case-control study examining the effects of active versus sedentary lifestyles on measures of body iron burden and oxidative stress in postmenopausal women. Biological Research for Nursing. 2014;16:38-45

132. Kortas J, Kuchta A, Prusik K, Prusik K, Ziemann E, Labudda S, et al. Nordic walking training attenuation of oxidative stress in association with a drop in body iron stores in elderly women. Biogerontology. 2017; 18:517-524

133. Hagner-Derengowska M, Kaluzny K, Kochanski B, Hagner W, Borkowska A, Czamara A, et al. Effects of nordic walking and pilates exercise programs on blood glucose and lipid profile in overweight and obese postmenopausal women in an experimental, nonrandomized, open-label, prospective controlled trial. Menopause. 2015;22:1215-1223

134. Wooten JS, Phillips MD, Mitchell JB, Patrizi R, Pleasant RN, Hein RM, et al. Resistance exercise and lipoproteins in postmenopausal women. Int J Sports Med. 2011;32:7-13

135. Mohanka M, Irwin M, Heckbert SR, Yasui Y, Sorensen B, Chubak J, et al. Serum lipoproteins in overweight/obese postmenopausal women: A one-year exercise trial. Medicine \& Science in Sports \& Exercise. 2006;38:231-239

136. Rossi FE, Fortaleza ACS, Neves LM, Buonani C, Picolo MR, Diniz TA, et al. Combined training (aerobic plus strength) potentiates a reduction in body fat but demonstrates no difference on the lipid profile in postmenopausal women when compared with aerobic training with a similar training load. Journal of Strength and Conditioning Research. 2016;30:226-234

137. Ozbey N, Sencer E, Molvalilar S, Orhan Y. Body fat distribution and cardiovascular disease risk factors in pre- and postmenopausal obese women with similar bmi. Endocrine Journal. 2002;49:503-509

138. Lopez-Candales A, Hernández Burgos PM, Hernandez-Suarez DF, Harris D. Linking chronic inflammation with cardiovascular disease: From normal aging to the metabolic syndrome. Journal of nature and science. 2017;3:e341

139. Stice JP, Lee JS, Pechenino AS, Knowlton AA. Estrogen, aging and the cardiovascular system. Future Cardiology. 2009;5:93-103

140. Lizcano F, Guzm, \#xe1, n G. Estrogen deficiency and the origin of obesity during menopause. BioMed Research International. 2014;2014:11

141. Gruzdeva OV, Akbasheva OE, Dyleva YA, Antonova LV, Matveeva VG, Uchasova EG, et al. Adipokine and cytokine profiles of epicardial and subcutaneous adipose tissue in patients with coronary heart disease. Bulletin of Experimental Biology and Medicine. 2017;163:608-611

142. Bertolami A, de Lima-Júnior JC, Cintra RM, Carvalho LS, Gonzaga CdC, Sulzbach ML, et al. Adiponectin concentration data improve the estimation of atherosclerotic risk in normal and in overweight subjects. Clinical Endocrinology. 2018;88:388-396

143. Iacobellis G, Ribaudo MC, Assael F, Vecci E, Tiberti C, Zappaterreno A, et al. Echocardiographic epicardial adipose tissue is related to anthropometric and clinical parameters of metabolic syndrome: A new indicator of cardiovascular risk. The Journal of Clinical Endocrinology \& Metabolism. 2003;88:5163-5168

144. Fisman EZ, Tenenbaum AJCD. Adiponectin: A manifold therapeutic target for metabolic syndrome, diabetes, and coronary disease? Cardiovascular Diabetology. 2014;13:103

145. Ibáñez J, Izquierdo M, Martínez-Labari C, Ortega F, Grijalba A, Forga L, et al. Resistance training improves cardiovascular risk factors in obese women despite a significative decrease in serum adiponectin levels. Obesity. 2010;18:535-541

146. Dekker JM, Funahashi T, Nijpels G, Pilz S, Stehouwer CDA, Snijder MB, et al. Prognostic value of adiponectin for cardiovascular disease and mortality. The Journal of Clinical Endocrinology \& Metabolism. 2008;93:1489-1496 
147. Teoh H, Strauss MH, Szmitko PE, Verma S. Adiponectin and myocardial infarction: A paradox or a paradigm?The opinions expressed in this article are not necessarily those of the editors of the european heart journal or of the european society of cardiology. European Heart Journal. 2006;27:2266-2268

148. Abella V, Scotece M, Conde J, Gómez R, Lois A, Pino J, et al. The potential of lipocalin-2/ngal as biomarker for inflammatory and metabolic diseases. Biomarkers. 2015;20:565-571

149. Ni J, Ma X, Zhou M, Pan X, Tang J, Hao Y, et al. Serum lipocalin-2 levels positively correlate with coronary artery disease and metabolic syndrome. Cardiovascular Diabetology. 2013;12:176

150. Sahinarslan A, Kocaman SA, Bas D, Akyel A, Ercin U, Zengin O, et al. Plasma neutrophil gelatinaseassociated lipocalin levels in acute myocardial infarction and stable coronary artery disease. Coronary Artery Disease. 2011;22:333-338

151. Wu G, Li H, Fang Q, Jiang S, Zhang L, Zhang J, et al. Elevated circulating lipocalin-2 levels independently predict incident cardiovascular events in men in a population-based cohort. Arteriosclerosis, Thrombosis, and Vascular Biology. 2014;34:2457-2464

152. Xiao Y, Xu A, Hui X, Zhou P, Li X, Zhong H, et al. Circulating lipocalin-2 and retinol-binding protein 4 are associated with intima-media thickness and subclinical atherosclerosis in patients with type 2 diabetes. PLOS ONE. 2013;8:e66607

153. Jamaluddin MS, Weakley SM, Yao Q, Chen C. Resistin: Functional roles and therapeutic considerations for cardiovascular disease. British journal of pharmacology. 2012;165:622-632

154. Lee T-S, Lin C-Y, Tsai J-Y, Wu Y-L, Su K-H, Lu K-Y, et al. Resistin increases lipid accumulation by affecting class a scavenger receptor, $\operatorname{cd} 36$ and atp-binding cassette transporter-al in macrophages. Life Sciences. 2009;84:97-104

155. Burnett MS, Lee CW, Kinnaird TD, Stabile E, Durrani S, Dullum MK, et al. The potential role of resistin in atherogenesis. Atherosclerosis. 2005;182:241-248

156. Verma S, Li S-H, Wang C-H, Fedak PWM, Li R-K, Weisel RD, et al. Resistin promotes endothelial cell activation. Circulation. 2003;108:736-740

157. Reilly MP, Lehrke M, Wolfe ML, Rohatgi A, Lazar MA, Rader DJ. Resistin is an inflammatory marker of atherosclerosis in humans. Circulation. 2005;111:932-939

158. Prestes J, Shiguemoto G, Botero JP, Frollini A, Dias R, Leite R, et al. Effects of resistance training on resistin, leptin, cytokines, and muscle force in elderly post-menopausal women. Journal of Sports Sciences. 2009;27:1607-1615

159. Prestes J, Nascimento DdC, Neto IVdS, Tibana RA, Shiguemoto GE, Perez SEdA, et al. The effects of muscle strength responsiveness to periodized resistance training on resistin, leptin, and cytokine in elderly postmenopausal women. The Journal of Strength \& Conditioning Research. 2018;32

160. Ramakrishna G, Rooke TW, Cooper LT. Iron and peripheral arterial disease: Revisiting the iron hypothesis in a different light. Vascular Medicine. 2003;8:203-210

161. You S-A, Archacki SR, Angheloiu G, Moravec CS, Rao S, Kinter M, et al. Proteomic approach to coronary atherosclerosis shows ferritin light chain as a significant marker: Evidence consistent with iron hypothesis in atherosclerosis. Physiological Genomics. 2003;13:25-30 


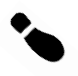

"Would you tell me, please, which way

I ought to go from here?"
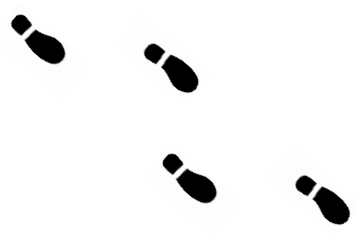

"That depends a good deal on

- where you want to get to."
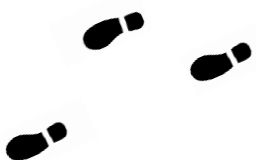

"I don't much care where -"
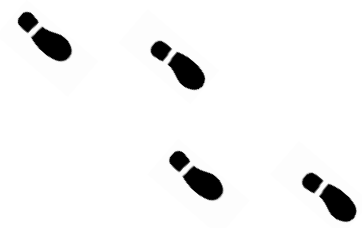

"Then it doesn't matter which way you go"
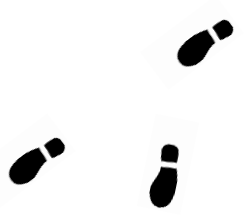

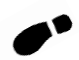

Alice and The Cheshire Cat Alice's Adventures in Wonderland by Lewis Carroll

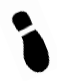




\section{Papers}

The papers associated with this thesis have been removed for copyright reasons. For more details about these see:

http://urn.kb.se/resolve?urn=urn:nbn:se:liu:diva-156366 


\section{FACULTY OF MEDICINE AND HEALTH SCIENCES}

Linköping University Medical Dissertation No. 1676, 2019

Department of Clinical and Experimental Medicine

Linköping University

SE-58183 Linköping, Sweden

www.liu.se

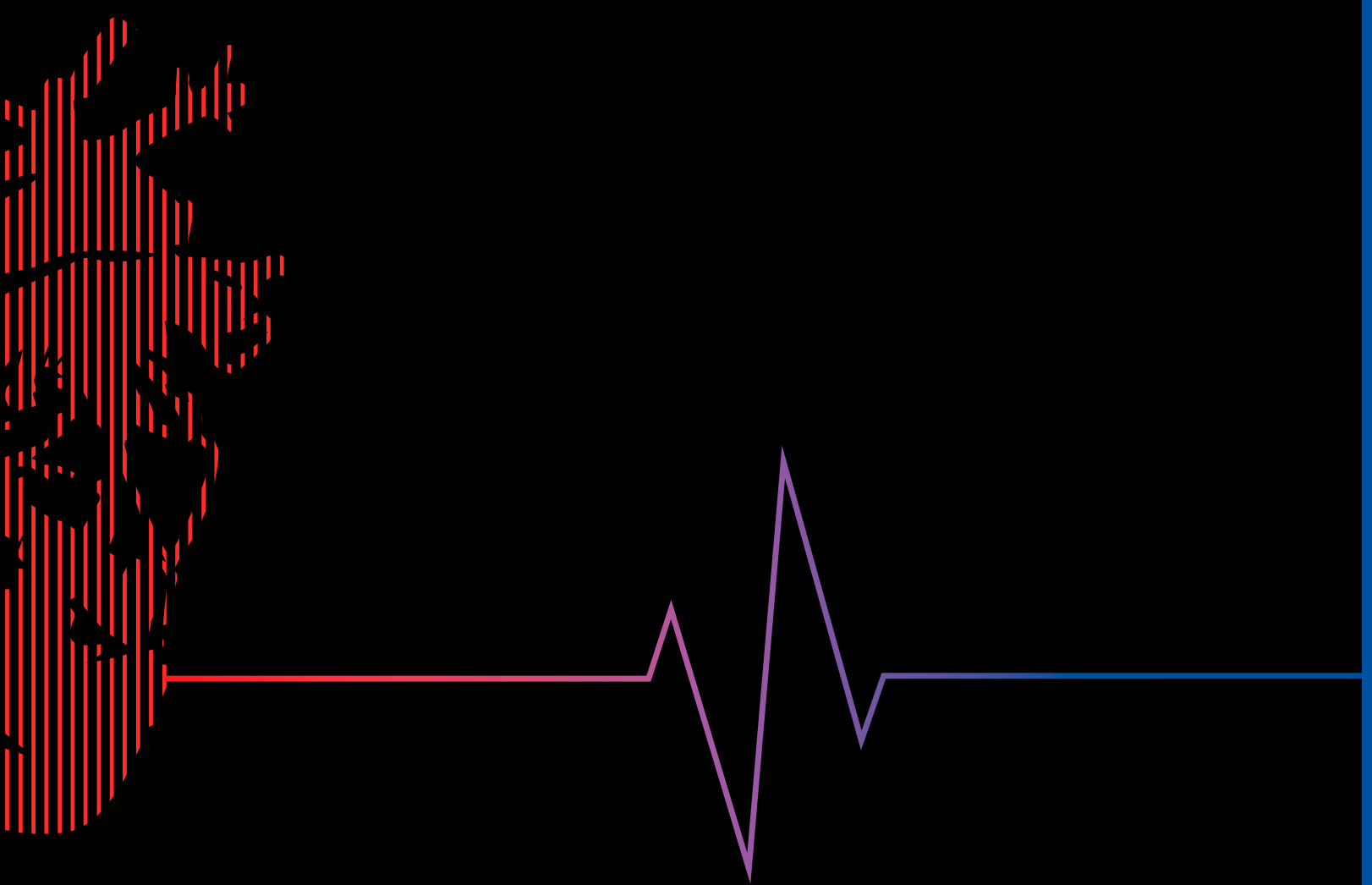

